\title{
Cork oak physiological responses to manipulated water availability in a Mediterranean woodland
} \author{
João S. Pereirab \\ a Centro de Geofísica da Universidade de Lisboa, Instituto Dom Luiz, Lisboa, Portugal \\ ${ }^{\mathrm{b}}$ Instituto Superior de Agronomia, Universidade técnica de Lisboa, Tapada da Ajuda, 1349-017 Lisboa, Portugal \\ c University College Dublin, Belfield, Dublin 4, Ireland \\ d Instituto Nacional de Recursos Biológicos, Quinta do Marquês, Av. da República, 2784-505 Oeiras, Portugal \\ e Universität Bayreuth, 95440 Bayreuth, Germany \\ ${ }^{\mathrm{f}}$ Harvard University, 22 Divinity Avenue, Cambridge, MA 02138, USA \\ ${ }^{g}$ Instituto de Technologia Química e Biológica, Av. da República, 2780-157 Oeiras, Portugal
}

Cathy Kurz Besson ${ }^{a, *}$, Raquel Lobo-do-Vale ${ }^{\mathrm{b}}$, Maria Lucília Rodrigues ${ }^{\mathrm{b}}$, Pedro Almeida ${ }^{\mathrm{b}}$, Alastair Herd ${ }^{\mathrm{b}}$, Olga Mary Grant ${ }^{\mathrm{c}}$, Teresa Soares David ${ }^{\mathrm{d}}$, Markus Schmidt ${ }^{\mathrm{e}}$, Denis Otieno ${ }^{\mathrm{e}}$, Trevor F. Keenan ${ }^{\mathrm{f}}$, Célia Gouveia ${ }^{\mathrm{a}}$, Catherine Mériaux ${ }^{\mathrm{a}}$, Maria Manuela Chaves ${ }^{\mathrm{b}, \mathrm{g}}$,

\section{A R T I C L E I N F O}

\section{Article history:}

Received 7 August 2012

Received in revised form 7 October 2013

Accepted 9 October 2013

\section{Keywords:}

Quercus suber

Throughfall manipulation

Tree transpiration

Gas exchange

Soil moisture

Precipitation change

\section{A B S T R A C T}

This study details the physiological responses of cork oak (Quercus suber L.) to manipulated water inputs. Treatments named as dry, ambient and wet, which received 80,100 and $120 \%$ of the annual precipitation, respectively, were applied to a Mediterranean woodland in southern Portugal. Tree ecophysiology and growth were monitored from 2003 to 2005.

The impacts of the water manipulation were primarily observed in tree transpiration, especially during summer drought. Rainfall exclusion reduced the annual stand canopy transpiration by $10 \%$ over the 2 -year study period, while irrigation increased it by $11 \%$. The accumulated tree transpiration matched precipitation in spring 2004 and 2005 at the stand level, suggesting that cork oak trees rely on precipitation water sources during the peak of the growing season. However, during the summer droughts, groundwater was the main water source for trees.

Despite the significant differences in soil water content and tree transpiration, no treatment effects could be detected in leaf water potential and leaf gas exchange, except for a single event after spring irrigations in the very dry year 2005. These irrigations were intentionally delayed to reduce dry spell duration during the peak of tree growing season. They resulted in an acute positive physiological response of trees from the wet treatment one week after the last irrigation event leading to a $32 \%$ raise of stem diameter increment the following months. Our results suggest that in a semi-arid environment precipitation changes in spring (amount and timing) have a stronger impact on cork oak physiology and growth than an overall change in the total annual precipitation.

The extreme drought of 2005 had a negative impact on tree growth. The annual increment of tree trunk diameter in the ambient and dry treatments was reduced, while it increased for trees from the wet treatment. Water shortage also significantly reduced leaf area. The latter dropped by $10.4 \%$ in response to the extreme drought of 2005 in trees from the ambient treatment. The reduction was less pronounced in trees of the wet treatment $(-7.6 \%)$, and more pronounced in trees of the dry treatment $(-14.7 \%)$.

Cork oak showed high resiliency to inter-annual precipitation variability. The annual accumulated tree transpiration, the minimum midday leaf water potential and the absolute amount of groundwater used

Abbreviations: $(A)$, carbon assimilation; $\left(A_{\max }\right)$, maximum carbon assimilation; $(C V)$, crown volume; $(D B H)$, diameter at breast height; $\left(D B H_{\text {inc }}\right)$, trunk diameter increment;

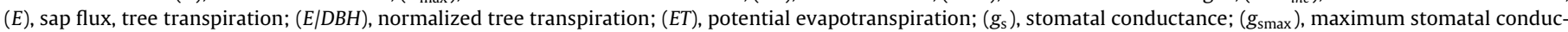

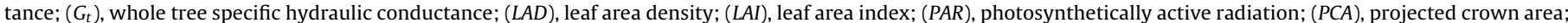

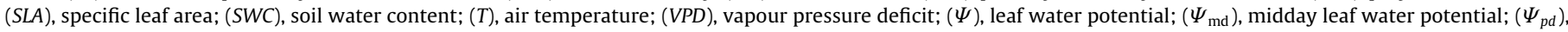

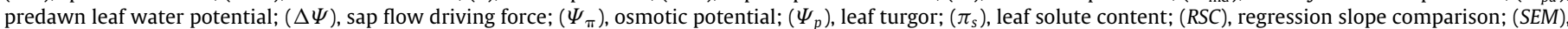
standard error of the mean.

* Corresponding author at: Instituto Dom Luiz, Centro de Geofísica da Universidade de Lisboa, Faculdade de Ciências, Campo Grande, Ed. C8, piso 3, Sala 26, 1749-016 Lisboa, Portugal. Tel.: +351 2175008 84; fax: +351 217500807.

E-mail addresses: cbbesson@fc.ul.pt, cathybesson@gmail.com (C.K. Besson), raquelvale@isa.utl.pt (R. Lobo-do-Vale), mlrodrigues@isa.utl.pt (M.L. Rodrigues),

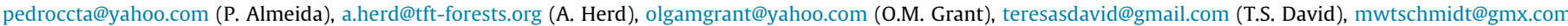

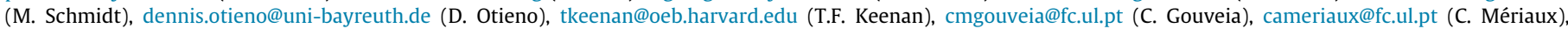
mchaves@isa.utl.pt (M.M. Chaves), jspereira@isa.utl.pt (J.S. Pereira). 
by trees appeared unaffected by the extreme drought of 2005. Our study shows that cork oak rapidly and completely recovered from the extreme dry year of 2005 or from rainfall exclusion. Our results support the eco-hydrological equilibrium theory by which plant acquire complementary protective mechanisms to buffer the large variability in water availability experienced in semi-arid ecosystems. In optimizing their structural biomass increase in response to increasing drought stress, cork oak trees succeeded in restricting water losses to maintain the minimum leaf water potential above the critical threshold of xylem embolism, though with narrower hydraulic safety margins in 2005.

Our findings highlight cork oak's sensitivity to the amount and timing of late spring precipitation. This could be critical as future climate scenarios predict a reduction of spring precipitation as well as enhanced severity of droughts in the Iberian Peninsula by the end of the 21st century. In inducing water stress before the onset of summer droughts, the predicted spring precipitation decline could drive the species closer to the threshold of catastrophic xylem embolism at the peak of the drought period.

(c) 2013 Elsevier B.V. All rights reserved.

\section{Introduction}

Mediterranean savanna-type evergreen oak woodlands are man-made ecosystems. They are characterized by a sparse native tree cover, which mostly consists of Quercus species (mainly evergreen cork oak, Quercus suber L., and/or holm oak, Quercus ilex ssp. rotundifolia Lam.) and understory vegetation ranging from shrub formations to grasslands. In Portugal, cork oak savanna-type ecosystems-montados-cover about 0.74 Mha and represent $23 \%$ of the national forested area (ICNF, 2013). The species has a significant economic value. It provides $0.7 \%$ of the gross domestic product, about 15,000 jobs, and supplies $54 \%$ of the worldwide cork production (Evangelista, 2010). Montados are also ecosystems with a high conservation value, supporting high levels of biodiversity (Bugalho et al., 2011), and are considered national heritage.

According to the most recent Portuguese forest inventories, montados show signs of an increasing vulnerability. In only 12 years, cork oak mortality rate and fire indices rose sharply (by $450 \%$ and $200 \%$, respectively) and tree density declined by $30 \%$ on average (AFN, 2001, 2010). All recent climate projections for the Mediterranean basin agree in forecasting future longer summer droughts, with more frequent extreme events, such as heat waves or severe droughts (Barriopedro et al., 2011; Coumou and Rahmstorf, 2012; Giorgi and Lionello, 2008; IPCC, 2007; Miranda et al., 2006). Projections also predict that spring and summer precipitation will decrease, by a magnitude ranging from -20 to $-40 \%$, depending on the climate change scenarios (Philandras et al., 2011; Giorgi and Lionello, 2008). Montados are mostly concentrated in the southern region of the country, which has scarce water resources and a long dry summer season usually coupled with high temperatures and high radiation (Faria et al., 1996). Under frequently limited water availability, Mediterranean plants evolved physiological and morphological adaptions to optimize water use (see review by Sardans and Peñuelas, 2013). Cork oak have acquired many features to cope with water stress and, ultimately, avoid xylem cavitation and embolism (Pereira et al., 2009). At the leaf level, stomatal closure induced by drought stress (Grant et al., 2010; Otieno et al., 2007; Pinto et al., 2012; Vaz et al., 2010) restricts water loss while limiting the rate of $\mathrm{CO}_{2}$ assimilation (Chaves, 1991; Farquhar and Sharkey, 1982). Biochemical constraints in the maximum Rubisco $\mathrm{CO}_{2}$ fixation capacity and the maximum rate of electron transport may also take place under prolonged drought conditions (Lawlor and Cornic, 2002; Lawlor and Tezara, 2009; Tezara et al., 1999) and be even more relevant under severe drought (Bota et al., 2004; Chaves et al., 2003, 2009; Grassi and Magnani, 2005; Vaz et al., 2010). Leaf osmotic adjustment improves water uptake capacity (Otieno et al., 2007). At the plant level, a deep rooting system enhances water uptake capacity via groundwater access (David et al., 2007) and hydraulic lift (Kurz-Besson et al., 2006; Otieno et al., 2006). The reduction of vessel diameter provides further resistance against xylem cavitation while the decrease of leaf area surface (Aranda et al., 2005; Chaves and Oliveira, 2004) avoids an excessive water loss.

These drought avoidance adaptations confer $Q$. suber with a high degree of resilience (Grant et al., 2010; Vaz et al., 2010). However, it remains uncertain whether these adaptations will allow plant survival under more extreme conditions as forecasted for the future. Therefore, there is a need for further rainfall manipulation studies to better predict the vulnerability of Mediterranean ecosystems under climate change (Beier et al., 2012; Wu et al., 2011).

Although cork oaks seem to be able to adapt to water scarcity in semi-arid ambients, the species has never been tested under the predicted future climatic conditions. This study aimed at evaluating $Q$. suber's physiological responses to rainfall manipulation so as to assess the vulnerability of Mediterranean Savannah-like ecosystems to future precipitation changes. Soil water availability was experimentally manipulated in a montado area in southern Portugal, by means of rainfall exclusion and addition. Treatments were designed according to the predicted range of precipitation changes in the Mediterranean basin (Giorgi and Lionello, 2008; Miranda et al., 2006). With increasing aridity, trees were expected to show progressively higher stomatal resistance, resulting in lower carbon assimilation rate, especially during the drought periods. These lower carbon assimilation rates would affect the carbon balance at the whole plant level leading to changed morphological and growth traits. Some uncertainties still remain on how higher stomatal resistance under increasing water shortage would affect the ecosystem water balance, which would experience lower transpiration rates but higher groundwater discharges.

Following the evolution of tree water status, sap flux, gas exchange, growth and morphological traits over two years of rainfall manipulation, our results show that not all the expectations were fulfilled. Finally, we discuss the relevance of spring precipitation quantity and distribution to cork oak's physiological performance in a particularly dry year.

\section{Material and methods}

\subsection{Experimental conditions}

The study was conducted in Herdade da Mitra (N $38^{\circ} 31.664^{\prime}$, W $8^{\circ} 01.380^{\prime}, 221 \mathrm{~m}$ altitude) in southern Portugal from 2003 to 2005. The climate is Mediterranean mesothermic humid. The experimental site lies on an acid Litholic non-Humic soil derived from Gneiss with a pH of $4-6$, on a $5 \%$ slope. From the surface to $1 \mathrm{~m}$ depth the soil consists of $88.9 \%$ sand, $4.9 \%$ silt, and $6.3 \%$ clay, with a low (5\%) water holding capacity. The experimental site $(46 \mathrm{~m} \times 60 \mathrm{~m})$ is covered with $Q$. suber $\mathrm{L}$. trees planted in 1988, with an understory mainly composed of Cistus salviifolius L. and C. crispus L. and herbaceous winter-spring $C_{3}$ annual plants. Twenty-seven representative $Q$. suber trees were selected for monitoring. The average tree density on the experimental site was $1997 \pm 134$ trees ha $^{-1}$. 
Table 1

Tree size characteristics and density at the beginning of the experiment in each treatment.

\begin{tabular}{|c|c|c|c|c|c|c|}
\hline & Tree Number & Height (m) & $D B H(\mathrm{~cm})$ & $L A I$ & $P C A\left(\mathrm{~m}^{2}\right)$ & Density (tree ha ${ }^{-1}$ ) \\
\hline \multicolumn{7}{|c|}{ Selected trees } \\
\hline W & 9 & $5.08(0.22)$ & $10.53(0.54)$ & $2.32(0.30)$ & $4.97(0.37)$ & ND \\
\hline A & 9 & $5.39(0.28)$ & $13.15(0.72)$ & $2.00(0.44)$ & $5.51(0.60)$ & ND \\
\hline $\mathrm{D}$ & 9 & $5.19(0.23)$ & $13.90(0.97)$ & $4.14(0.59)$ & $4.59(0.43)$ & ND \\
\hline \multicolumn{7}{|c|}{ Experimental area } \\
\hline W & 125 & $2.28(0.16)$ & $3.86(0.40)$ & $0.90(0.12)$ & $2.01(0.17)$ & 2001 \\
\hline A & 137 & $2.23(0.14)$ & $3.93(0.40)$ & $0.84(0.10)$ & $1.97(0.15)$ & 2360 \\
\hline $\mathrm{D}$ & 103 & $2.50(0.19)$ & $4.71(0.53)$ & $1.07(0.14)$ & $2.27(0.20)$ & 1724 \\
\hline
\end{tabular}

Tree density in each treatment area was within the confidence interval of the mean $[1570 ; 2424]$ of the entire stand. Tree density, height, and diameter at breast height $(D B H)$ measured at the beginning of the experiment are provided in Table 1.

From late October 2003 onwards and in accordance with predictions of a $20 \%$ reduction in precipitation (Miranda et al., 2006), three treatments (ambient, dry and wet) were applied within the site. Rainfall exclusion was achieved by placing $0.6 \mathrm{~m}$ wide $\times 20 \mathrm{~m}$ long plastic drains covering $20 \%$ of the soil surface and located between tree rows under open canopy area. The drains were installed on a $5 \%$ slope allowing water to flow naturally down to a reservoir that was later being used for irrigation. Considering that $24 \%$ of the exclusion area was covered by tree canopy and that cork oak interception was $22 \%$ of gross rainfall (David 2000), we calculated that rainfall interception slightly reduced the exclusion efficiency from an expected $20 \%$ excluded rainfall to an effective $19 \%$. The control 'ambient' treatment received natural rainfall while the 'wet' treatment received extra precipitation, diverted from the 'dry' treatment. Water collected over the dry treatment plots was redistributed from the reservoir, onto the wet treatment plots, via irrigation pipes with drip emitters. Each treatment was replicated over three blocks and physiological data were recorded in three trees per treatment per block ( 9 blocks). A block design was used to take into account potential variation due to the slope of the experimental site ( $10 \mathrm{~m}$ altitude difference within the site). Rainfall exclusion and irrigation started at the end of November 2003. Due to the severe drought during 2004/2005, the wet treatment was supplied with additional water between July 2004 and June 2005 (126\% of the rainfall occurring in the ambient treatment). Fig. 1 shows the total amount of water received by each treatment in 2003, 2004 and 2005 compared to the average of the 30 -year period 1951-1980 (INMG, 1991).

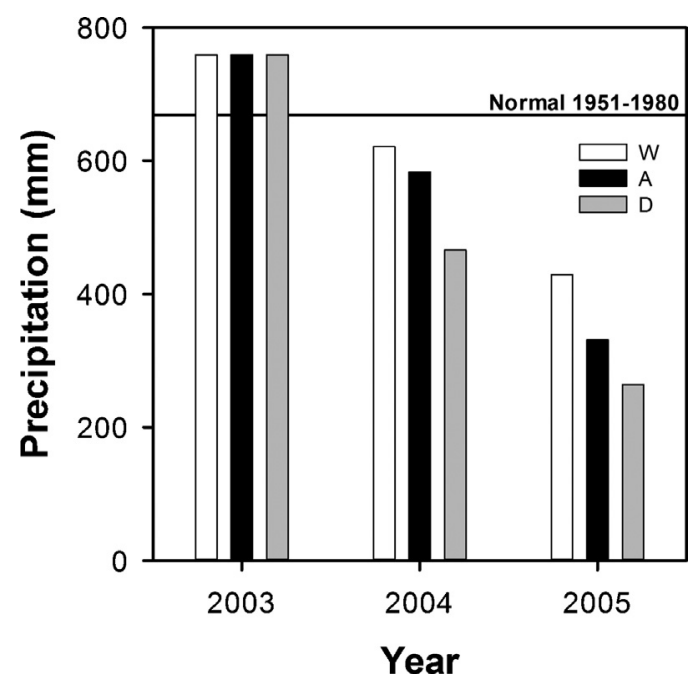

Fig. 1. Annual precipitation for each treatment compared to the 30-year average annual precipitation (1951-1980) (horizontal line).

\subsection{Environmental monitoring}

Precipitation (ARG100 rain gauge, EM Ltd., Sunderland, UK), air humidity (Fischer 431402 sensor, K. Fischer GmbH, Drebach, Germany), air temperature $(T)$ at $2 \mathrm{~m}$ height (Thermistor M841, Siemens, Munich, Germany) and photosynthetically active radiation (PAR, LI-190 quantum sensor, Licor Inc., Lincoln, NB, USA) were measured with a datalogger (DL2e, Delta-T Devices Ltd., Cambridge, UK) every $5 \mathrm{~min}$, recording 30-min averages based on the Coordinated Universal Time/Greenwich Mean Time. Air vapour pressure deficit (VPD) was calculated from the equation proposed by Wesely (1989).

From December 2003 to October 2004, soil water content (SWC) was measured by frequency domain technology using echo probes (ECH20, Decagon, Decagon Devices Inc., Washington, USA). SWC was continuously measured at $0.1,0.2$ and $0.3 \mathrm{~m}$ depth in one location of each of the 9 plots. As the echo probes suffered from a poor sensor contact with the soil during the drought periods, the continuous monitoring of SWC was replaced by weekly measurements using a profile probe (PR2, Delta-T Devices Ltd., Cambridge, UK) from January to September 2005. Profile probe SWC measurements were performed at 6 depths simultaneously $(0.1,0.2,0.3,0.4$, $0.6,1 \mathrm{~m})$, on 3 locations in each of the 9 plots. Gravimetric measurements were performed periodically to calibrate soil moisture sensors.

We will consider here hydrological years (between October of the previous year and September of the current year), as it reflects better the available water for tree functioning and growth.

\subsection{Sap flow and hydraulic conductance}

Tree sap flow was measured using thermal dissipation sensor probes of $20 \mathrm{~mm}$ length (UP GmbH, Landshut, Germany) according to the Granier method (David et al., 2007; Granier, 1985). One sensor was radially inserted in the north-facing xylem of each tree at breast height. Sensors were connected to a datalogger (DL2e, DeltaT Devices Ltd., Cambridge, UK), reading temperature differences $(\Delta T)$ between probes every minute and recording 30 -min averages. Sap flow was continuously measured on 25 selected trees from June 2003 to October 2005. Data from 6 trees were discarded as their recording had more than $65 \%$ gap due to repetitive sensor failures. Missing values in the remaining data sets, equivalent to $29 \%$ of total recordings, were filled using linear relationships between sensors showing an average determination coefficient of 0.77 . The tree transpiration $(E)$ was calculated by multiplying the sap flux density by the conductive sapwood area, which was assumed to be the $20 \mathrm{~mm}$-wide annulus of sapwood in contact with the sapflow sensor. A detailed description of the sensors and sap flow calculation can be found in David et al. (2004).

$E$ expressed in $\mathrm{Lday}^{-1}$ was best normalized to tree diameter at breast height $\left(E / D B H\right.$, expressed in $\left.\mathrm{L} \mathrm{m}^{-1} \mathrm{day}^{-1}\right) . E / D B H$ results are presented as 9-day running averages. Whole tree specific hydraulic conductance $\left(G_{t}\right)$ was estimated according to Darcy's law dividing the normalized daily sap flow $(E / D B H)$ by the sap flow driving 
force $(\Delta \Psi)$ (Bucci et al., 2005; Cochard et al., 1996). $\Delta \Psi$ was calculated by substracting midday $\left(\Psi_{m d}\right)$ from predawn $\left(\Psi_{p d}\right)$ leaf water potential.

Tree transpiration was up-scaled to the stand level by calculating the best daily linear regression between the sap flux of the remaining 19 monitored trees and their corresponding $D B H$ or height. The daily relationships were then applied on each of the 479 trees covering the experimental area for which $D B H$ and height had been measured in 2003 before treatment implementation.

\subsection{Leaf water status and gas exchange}

Daily courses of leaf water potential $(\Psi)$ and gas exchange were performed simultaneously in clear days throughout the year, and on a monthly basis during drought periods (see dates on Table 2). Three mature leaves per tree were sampled for each measurement at 0600 (only $\Psi$ ), 1000, 1300 and 1600 h.

$\Psi$ was measured with a pressure chamber (PMS Instrument Co., Corvallis, Oregon, USA). Immediately after measuring predawn leaf water potential $\left(\Psi_{p d}\right)$, discs of each leaf were taken, placed in Eppendorfs, and plunged into liquid nitrogen until being stored at $-80^{\circ} \mathrm{C}$ for later determination of osmotic potential $\left(\Psi_{\pi}\right)$. After thawing the samples for $10 \mathrm{~min}$ at room temperature, $\Psi_{\pi}$ was measured using C52 chambers ( $2 \mathrm{~h}$ for temperature and water vapour equilibration) connected to a Wescor HR 33T dew-point microvoltmeter (Wescor Inc., USA) operating in dewpoint mode. Standard $\mathrm{NaCl}$ solutions were used for each chamber calibration, generating a calibration regression used to convert the $\mu \mathrm{v}$ output to $\Psi_{\pi}$ in MPa. Leaf turgor $\left(\Psi_{p}\right)$ was estimated as the difference between $\Psi_{p d}$ and $\Psi_{\pi}$. Leaf solute content $\left(\pi_{s}\right)$ was calculated as $\pi_{s}=-\Psi_{\pi}(V / R T)$ where $R$ is the universal gas constant, $T$ is the leaf temperature and $V$ is the total volume of water in the leaf tissue. $V$ was determined in another set of discs punched from the same leaves and expressed on leaf dry mass basis.

Leaf gas exchange measurements were performed with two cross-calibrated portable photosynthesis systems (Li-6400; Licor Inc., Lincoln, $\mathrm{NB}, \mathrm{USA}$ ). The diurnal changes in $\mathrm{CO}_{2}$ assimilation $(A)$ and stomatal conductance $\left(g_{s}\right)$ were recorded after stabilization. Environmental conditions (air temperature $T$, vapour pressure deficit VPD and photosynthetic photon flux density PPFD) were monitored with the LI-6400 system. Maximal rates of photosynthesis $\left(A_{\max }\right)$ and stomatal conductance $\left(g_{\mathrm{smax}}\right)$ were determined from daily courses.

\subsection{Tree morphological traits and growth}

Stem diameter was measured at breast height $(D B H)$ using tree dendrometers (I-802-D1, UMS GmbH, Munich, Germany). The annual $D B H$ increment $\left(D B H_{i n c}\right)$ was calculated as a percentage based on hydrological years (2004 and 2005). Tree heights were measured with a telescopic height pole. Spherical lens photographs (HemiView System-HMV1, Delta-T Devices Ltd., Cambridge, UK) were also taken at dawn in September 2003, March 2004 and October 2005 on the south and north sides of the 27 selected trees. Crown base diameter $(D)$, height and geometrical shape were recorded for each selected tree. These parameters were used within the Hemiview software to determine tree leaf area index (LAI, one-side leaf area per projected crown area), crown volume (CV) according to tree crown geometrical shape, and projected crown area (PCA) calculated as $1 / 4 \pi D^{2}$ (Berlyn, 1962; Watson, 1947). Leaf area density $(L A D)$ was determined from the ratio between $L A I$ and $C V$. Specific leaf area (SLA) was calculated by dividing the leaf area to the dry weight of 6 leaf discs $(0.7 \mathrm{~cm}$ diameter) collected from 3 leaves sampled on each selected tree in September 2004 and 2005.

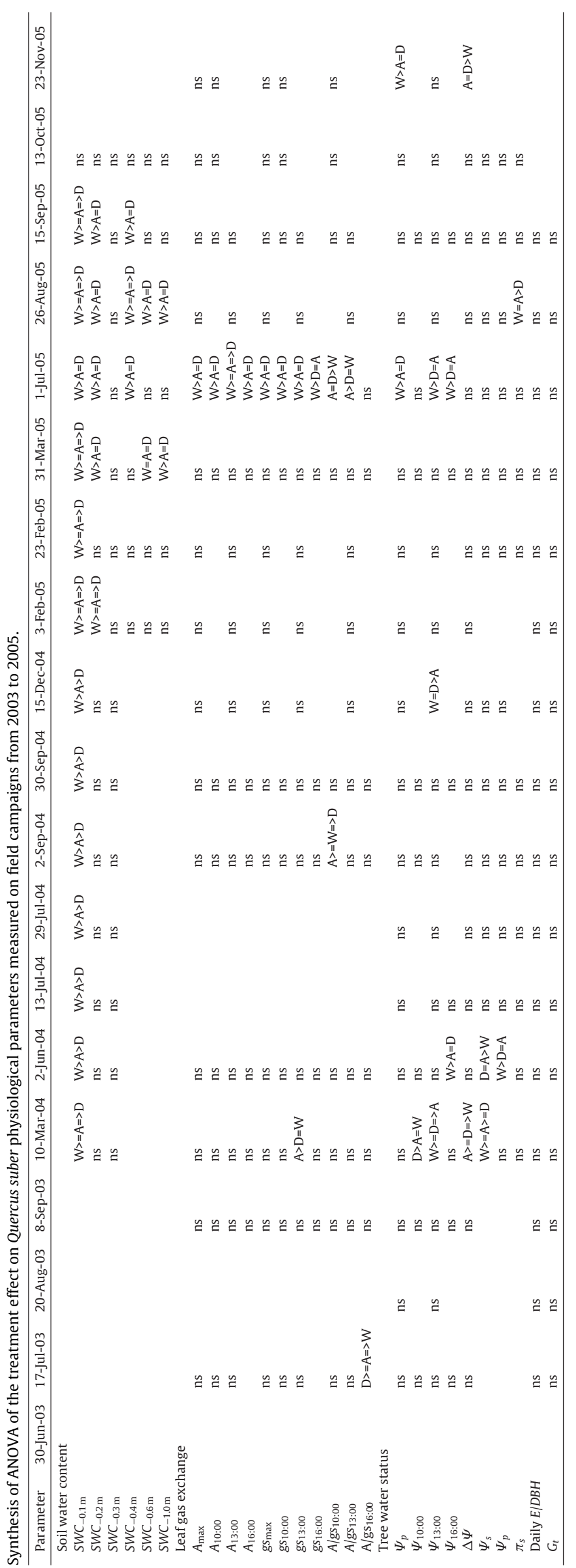




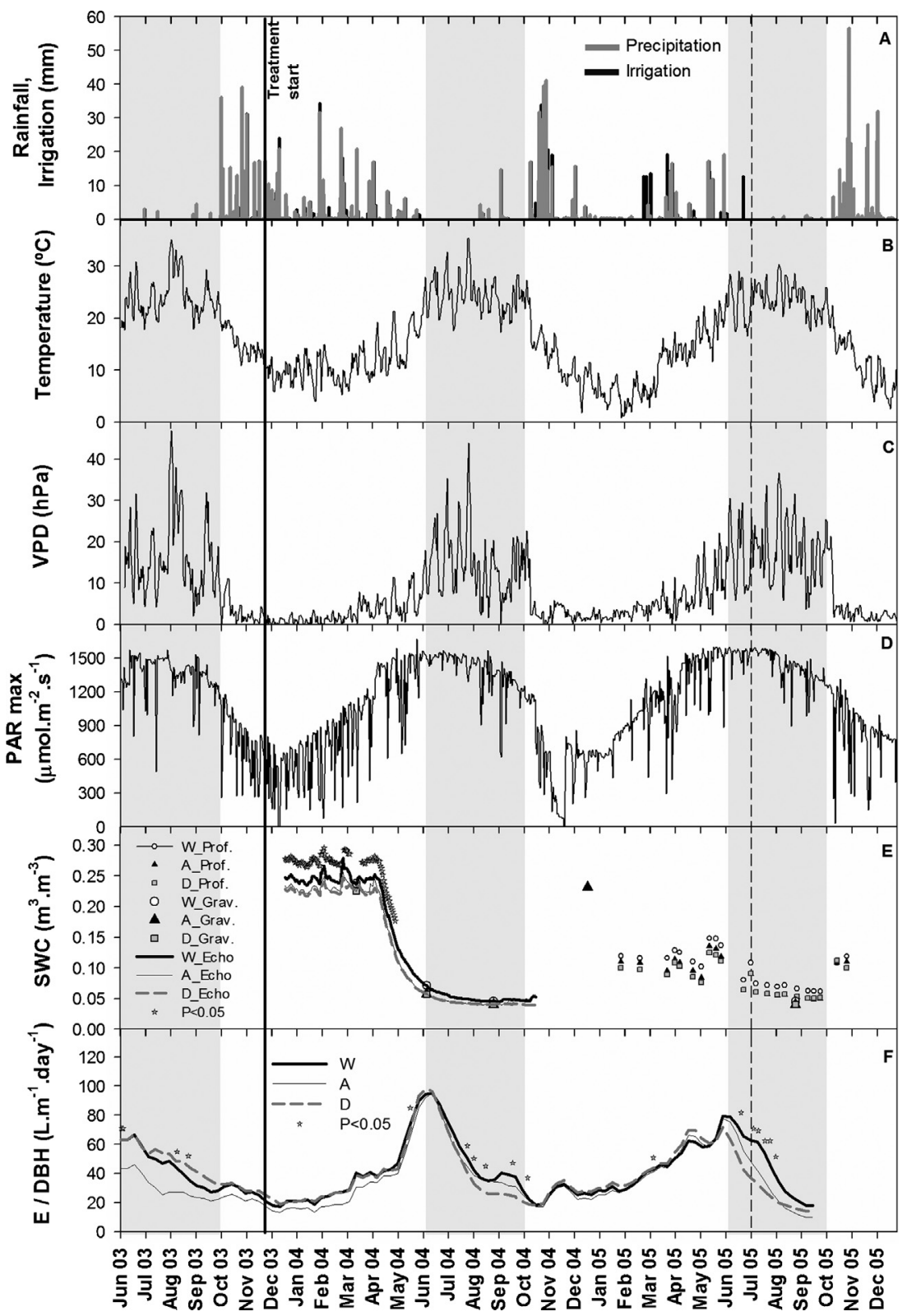

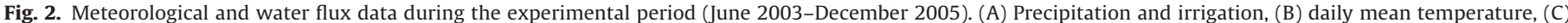

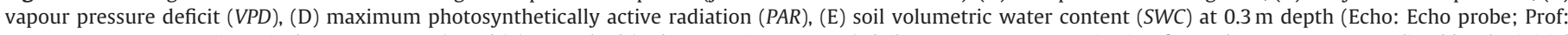

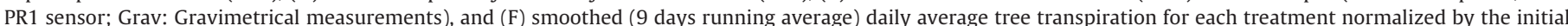

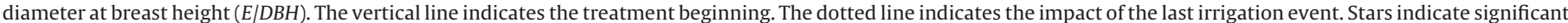
differences between treatment means $(P<0.05)$. Grey background indicates summer drought periods.

\subsection{Statistical analysis and data processing}

To assess the effect of precipitation changes on the parameters measured, a one-way mixed model analysis of variance (ANOVA) was used, considering treatments as a fixed factor and blocks as a random factor. When a statistically significant effect $(p<0.05)$ of the treatment was found, the post hoc Tukey HSD test was used to identify differences between means. Statistical analyses and linear regression fits were carried out with SAS 9.1 (SAS Institute, Cary, NC, USA). Data were transformed when necessary to meet the assumptions of parametric analyses. Statistical comparisons of regression slopes $(R S C)$ followed the analysis of covariance method described by Zar (1999). Time-by-time ANOVA was performed on the derived monitored variables (E/DBH and $S W C$ ) to reduce autocorrelation and emphasize treatment effect (Diggle et al., 2002). In the text and figures, mean values are presented with standard error of the mean (SEM).

\section{Results}

\subsection{Environmental drivers}

The experiment covered three highly contrasting hydrological years varying from typical in 2003, to moderately dry in 2004, and severely dry in 2005 (Fig. 1). Annual rainfall amounts were $689 \mathrm{~mm}, 607 \mathrm{~mm}$ and $410 \mathrm{~mm}$ in 2003, 2004 and 2005, respectively (Fig. 1). In 2004, rainfall events occurred mainly from October to May and were more frequent and intense during autumn (Fig. 2A) 2005 was characterized by unusually low precipitations between November and March. Spring precipitation was lower in 2004 than 


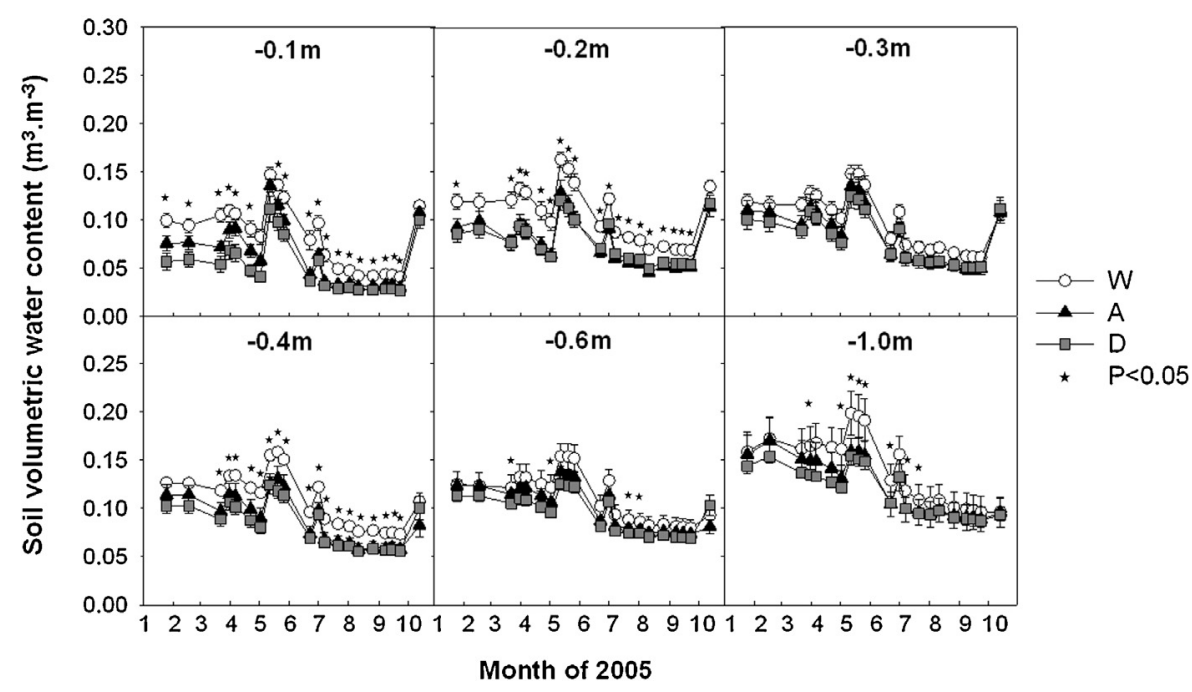

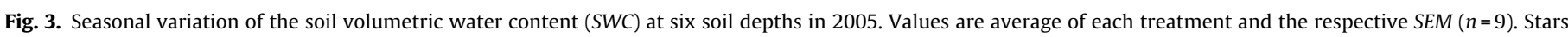
indicate significant differences between treatment means $(P<0.05)$.

in 2005 ( $51 \mathrm{~mm}$ and $78 \mathrm{~mm}$, respectively), whereas summer rainfall decreased substantially over the time $(50 \mathrm{~mm}, 26 \mathrm{~mm}$ and $4 \mathrm{~mm}$ in 2003, 2004 and 2005, respectively). The last significant rainfall events of 2005 occurred on May 16th $(12 \mathrm{~mm})$ and 30th $(19 \mathrm{~mm})$. The last irrigation was intentionally delayed to June 22th (13 mm). The mean daily T, VPD and daily maximum PAR followed typical Mediterranean seasonal trends (Miranda et al., 2006), with high values during the summer (Fig. 2B, C and-D).

$S W C$ at $0.3 \mathrm{~m}$ depth (Fig. $2 \mathrm{E}$ ), where most of the fine tree roots are found, was close to field capacity from December to March 2004, averaging $0.23 \pm 0.01 \mathrm{~m}^{3} \mathrm{~m}^{-3}$. Compared with the ambient treatment, SWC was higher in the wet treatment (+11\%) and slightly lower in the dry treatment (3\%). During spring (April-June) 2004, SWC dropped steeply in response to the lack of rainfall. The soil permanent wilting point was reached during summer (July, $0.04 \pm 0.01 \mathrm{~m}^{3} \mathrm{~m}^{-3}$ ) with no significant difference between treatments, and persisted until October. Soil recovered field capacity during winter (December) following a rainy period. From the end of December 2004 to the middle of February 2005, rainfall events were rare and weak $(<2 \mathrm{~mm})$ resulting in low winter $S W C$ values (overall mean was $0.13 \pm 0.01 \mathrm{~m}^{3} \mathrm{~m}^{-3}$ ). At the end of the summer 2005, the soil moisture reached permanent wilting point again with SWC averaging $0.05 \pm 0.003 \mathrm{~m}^{3} \mathrm{~m}^{-3}$. By the end of October, $S W C$ was $0.11 \pm 0.01 \mathrm{~m}^{3} \mathrm{~m}^{-3}$. Differences in $S W C$ at $0.3 \mathrm{~m}$ between treatments were not significant. SWC in the other soil horizons is summarized in Table 2 and Fig. 3 . At $0.1 \mathrm{~m}$ depth, a consistent significant difference between the wet and dry treatments was observed with a higher SWC in the wet plots, except in October 2005 . At $0.2 \mathrm{~m}$ depth, SWC was significantly higher in the wet plots compared to the dry and ambient plots from February to September 2005. At deeper horizons ( 0.4 to $1 \mathrm{~m}$ depth), however, soil became significantly wetter in the wet treatment from late March 2005 until late August 2005. The increase in SWC observed at the onset of fall rain events in 2005 diminished with increasing soil depth and remained very small at $1 \mathrm{~m}$ depth.

\subsection{Cork oak physiological responses}

\subsubsection{Tree transpiration and hydraulic conductance}

E/DBH followed the VPD seasonal trend (Fig. 2C, F) with maximum values reached at the beginning of June. Maximum $E / D B H$ was observed in June 2004, with values ranging from 96.63 to $113.71 \mathrm{~L} \mathrm{~m}^{-1} \mathrm{day}^{-1}$. In June 2005 , one week after the last $13 \mathrm{~mm}$ irrigation pulse, $E / D B H$ showed a $45 \%$ increase in the wet treatment associated to a raise of soil water content at $0.3 \mathrm{~m}$ depth (vertical dashed line, Fig. 2E and F). In fall and winter 2003 and 2004 and in early spring 2004 and 2005, there was no significant difference in tree transpiration between the 3 treatments (Fig. 2F). However, during the summer periods of 2004 and 2005, treatment effects could be detected on several occasions, with significantly lower sap flux in the dry treatment than in the two other ones. Significant treatment effects were more frequent after the last $13 \mathrm{~mm}$ irrigation with higher values in the wet treatment compared with the dry one (Fig. 2F).

$E / D B H$ was $44 \%$ higher in spring 2005 than in spring 2004. It was likely due to the higher amount of precipitation in Spring 2005 (Fig. 2F and Table 3). There was no significant effect of the treatment on the accumulated transpiration at the tree level (Fig. 4A). Between May 16th and June 6th there was hardly any $E / D B H$ difference between trees from the different treatments. Tree transpiration began to differ between treatments 7 days after the last heavy rainfall of May 30th 2005, highlighting a substantial positive effect of the last irrigation pulse from this date onwards. The transpiration rate increased by $42 \%$ for trees of the wet treatment and it remained $66 \%$ higher on average than the one of the ambient treatment until September 15th (Fig. 5).

Table 3

Seasonal stand accumulated transpiration (normalized to tree density $\times$ mean $D B H$ ) as compared to seasonal accumulated rainfall in 2004 and 2005.

\begin{tabular}{lll}
$\begin{array}{l}\text { Stand cumulated } \\
\text { transpiration }(\mathrm{mm})\end{array}$ & Rainfall $(\mathrm{mm})$ & $\begin{array}{l}\text { Groundwater } \\
\text { contribution } \\
(\%)\end{array}$ \\
\hline W A D &
\end{tabular}

\begin{tabular}{lrrrrr}
\multicolumn{1}{c}{ W } & \multicolumn{1}{c}{ A } & & \\
\hline $\mathbf{2 0 0 4}$ & & & & & 0 \\
Fall (OND) & 14 & 13 & 16 & 331 & 0 \\
Winter (JFM) & 18 & 16 & 19 & 198 & 0 \\
Spring (AMJ) & 52 & 53 & 50 & 51 & 57 \\
Summer (JAS) & 70 & 62 & 45 & 26 & \\
Total & 154 & 142 & 131 & 607 & 0 \\
$\mathbf{2 0 0 5}$ & & & & & 0 \\
Fall (OND) & 18 & 19 & 20 & 277 & 86 \\
Winter (JFM) & 25 & 27 & 28 & 51 & \\
Spring (AMJ) & 84 & 80 & 64 & 78 & 4 \\
Summer (JAS) & 46 & 28 & 23 & 43 & \\
Total & 174 & 153 & 134 & 410 & \\
\hline
\end{tabular}




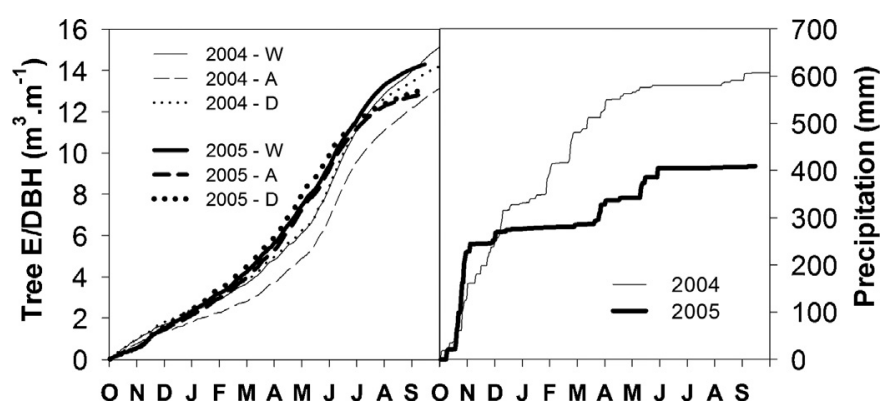

Fig. 4. (A) Accumulated transpiration at the tree level in response to the wet, ambient, and dry treatments compared with the (B) accumulated precipitation in 2004 (thin line) and 2005 (thick line).

Up-scaled at the stand level, the canopy transpiration most suffered from rainfall exclusion in the summer (27\% lower in 2004, and $20 \%$ in 2005 than in the ambient area). On an annual basis, rainfall exclusion reduced the stand canopy transpiration in the dry plots by $8 \%$ in 2004 , and $13 \%$ in 2005 . Irrigation had a high positive impact in summer, increasing canopy transpiration by $14 \%$ in 2004 and $63 \%$ in 2005. Irrigation also increased the annual stand canopy transpiration by $8 \%$ in 2004 and $13 \%$ in 2005 . In spring the accumulated stand canopy transpiration well matched the accumulated precipitation. The total accumulated stand transpiration observed in 2005 (134-174 mm, Fig. 4B) was unaffected by the lower annual precipitation $(410 \mathrm{~mm})$ when compared with the total accumulated transpiration (131-154 $\mathrm{mm}$ ) and higher annual precipitation $(607 \mathrm{~mm}$ ) of 2004. Moreover, the absolute contribution of groundwater to tree transpiration over the 2004 and 2005 summer periods was $35 \mathrm{~mm}$ and $24 \mathrm{~mm}$, respectively (Table 3 ), which overall were very similar values.

\subsubsection{Leaf water relations}

Leaf water potential measurements performed during summer 2003 (before the beginning of water manipulation) showed close

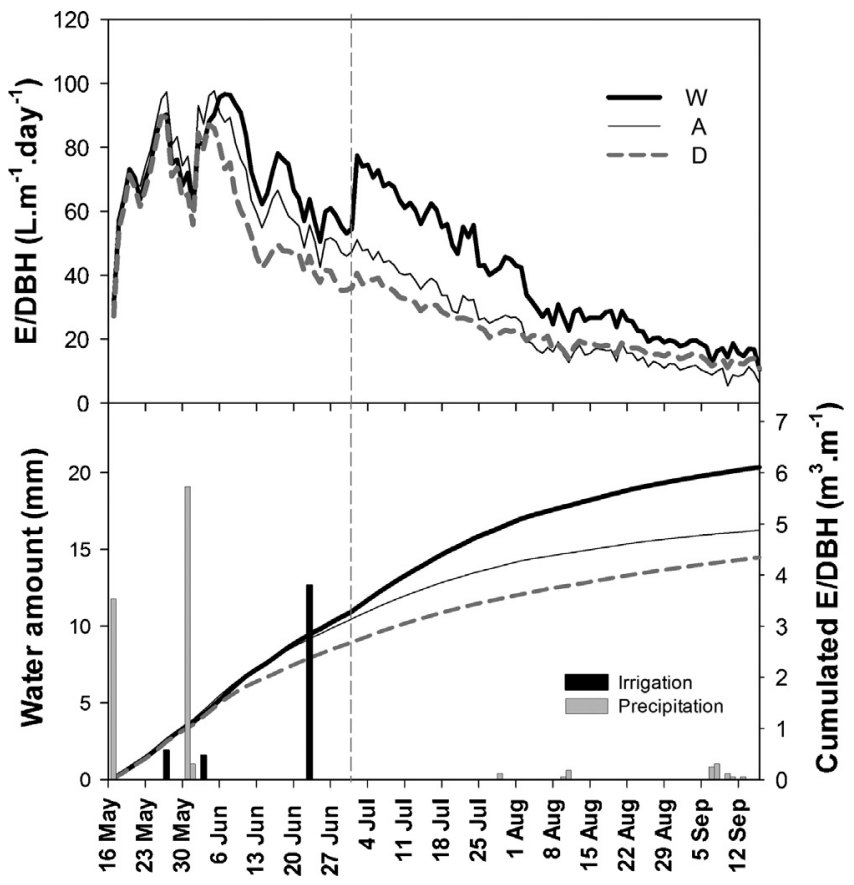

Fig. 5. Mean daily (top) and accumulated $E / D B H$ (bottom) for trees from the wet $(\mathrm{W})$, ambient (A) and dry (D) plots in response of spring rainfalls and irrigation in 2005. The vertical dashed line indicates the date at which the last irrigation began to have an effect on tree transpiration.

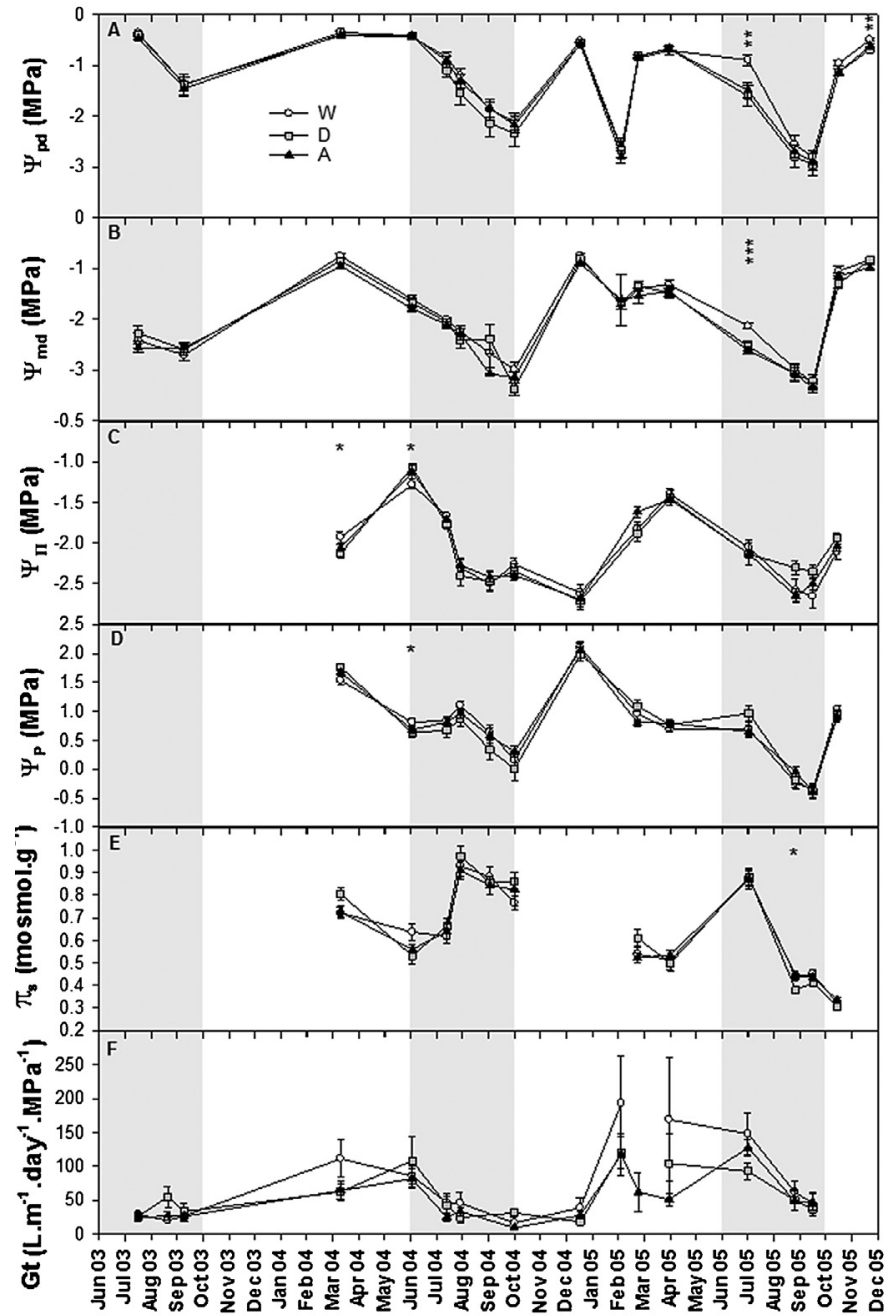

Fig. 6. Evolution of (A) leaf predawn water potential $\left(\Psi_{p d}\right)$,(B) midday water potential $\left(\Psi_{m d}\right),(\mathrm{C})$ osmotic potential $\left(\Psi_{\pi}\right)$, (D) turgor potential $\left(\Psi_{p}\right)$, (E) solute content $\left(\pi_{s}\right)$ and $(F)$ hydraulic conductance $\left(G_{t}\right)$ of selected trees in response to the wet, ambient and dry treatments from 2003 to 2005. Values are average of each treatment with the respective $\operatorname{SEM}(n=9)$. Significant differences between treatments are indicated for ${ }^{*} P<0.05,{ }^{* *} P<0.01,{ }^{* * *} P<0.001$. Grey background indicates summer drought periods.

similarity between treatments. A seasonal trend of $\Psi$ could be distinguished over the three years, both at predawn and midday. The trees showed a high leaf water status during the winter and spring but were severely stressed at the end of the summer drought, in September (Fig. 6A-B). Significant differences between treatments were only observed on July 1 st $2005\left(\Psi_{p d}\right.$ and $\left.\Psi_{m d}\right)$ and on November 24th 2005 ( $\Psi_{p d}$ only), where trees form the wet treatment showed a higher water status (Table 2 and Fig. 6A-B). $\Psi_{p d}$ gradually declined throughout the summer and inter-annually with particularly low values in 2005 at the end of the drought periods. At the end of the experiment after autumn rainfalls, a fast recovery of the plant water status was observed, especially in the trees of the wet treatment. There was a statistically significant difference in minimum $\Psi_{p d}$ between years $(p<0.001)$, with overall means of $-1.40 \pm 0.05,-2.21 \pm 0.07$ and $-2.88 \pm 0.05 \mathrm{MPa}$ in September 2003, 2004 and 2005, respectively (Fig. 6A).

Minimum $\Psi_{m d}$, (Fig. 6B) decreased significantly from 2003 $(-2.62 \pm 0.06 \mathrm{MPa})$ to $2004(-3.17 \pm 0.08 \mathrm{MPa})$ but did not show a further significant decrease in $2005(-3.28 \pm 0.06 \mathrm{MPa})$.

Low $\Psi_{p d}(-2.47+-0.13 \mathrm{MPa})$ was measured in February 2005 due to low temperatures $\left(<-2{ }^{\circ} \mathrm{C}\right)$ at night. This suggested possible 


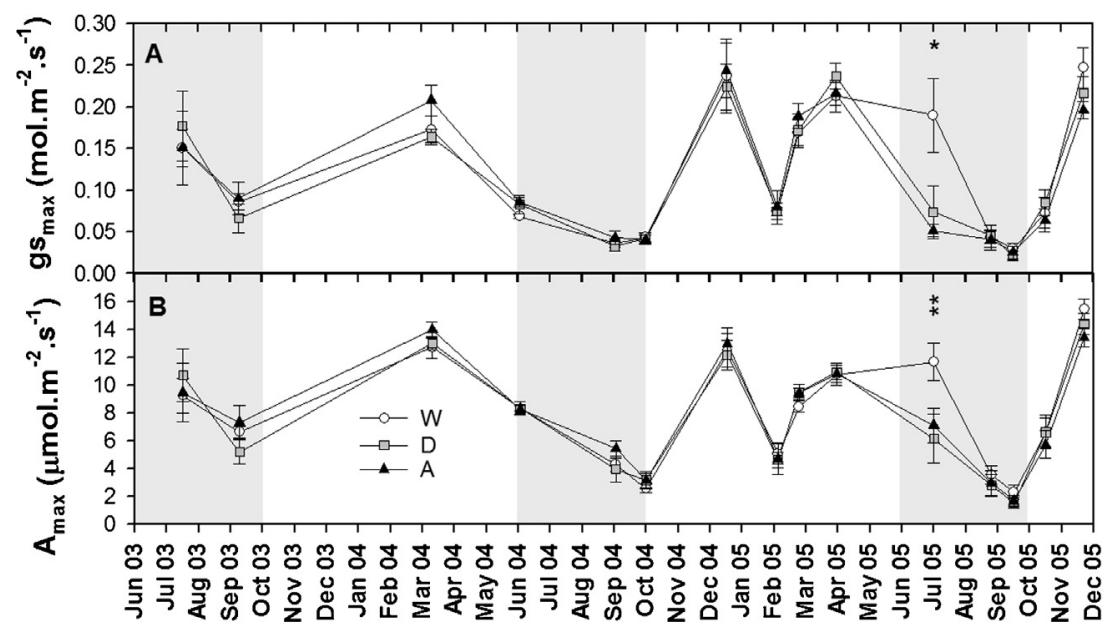

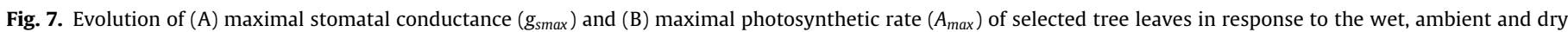
treatments from 2003 to 2005 . Significant differences between treatments are indicated when ${ }^{*} P<0.05$, ${ }^{* *} P<0.01$. Grey background indicates summer drought periods.

frozen water in leaf vessels. However, the higher $\Psi_{m d}$ measured $(-1.50+-0.12 \mathrm{MPa})$ a few hours after the freezing night, when day temperature had reached $12^{\circ} \mathrm{C}$, indicated that leaves had quickly recovered from the frost and did not suffer irreversible damage.

In response to increasing drought a marked decline in $\Psi_{\pi}$ was observed in 2004 and 2005 accompanied by an increase in the amount of leaf solutes per unit dry mass indicating that a seasonal osmotic adjustment had occurred in trees under the 3 treatments (Fig. 6C and E). In $2004 \Psi_{\pi}$ decreased from June (mean ranging from 1.07 and $-1.28 \mathrm{MPa}$ ) to September ( -2.42 to $-2.51 \mathrm{MPa}$ ). A similar decrease of $\Psi_{\pi}$ was observed in 2005 after April. Significant differences in $\Psi_{\pi}$ among treatments were only detected in March and June 2004 when the soil water availability was still high and favouring tree water status (Table 2 and Fig. 6C). In both years leaf turgor decreased from July onwards due to the seasonal reduction of $\Psi_{p d}$ unmatched by a proportional decrease of $\Psi_{\pi}$ (Fig. 6D). Whereas $\Psi_{p}$ was still positive by the end of the 2004 drought period, turgor loss point was reached earlier in 2005, in August. Differences in $\Psi_{p}$ between treatments were observed on June 2nd 2004 when the $\Psi_{p}$ value of wet treatment trees became higher than that of the ambient and dry treatments, due to lower $\Psi_{\pi}$ (Table 2; Fig. 6D and E).

While in 2004 the leaf solute concentration was high throughout the drought period $\left(>0.77 \mathrm{mosmol} \mathrm{g}^{-1}\right)$, a decrease of $\pi_{s}$ was observed in the mid-summer of $2005\left(<0.45\right.$ mosmol g $\left.^{-1}\right)$ probably in response to the high intensity of water stress experienced by the trees (Fig. 6E). Leaf solute content did not differ in the three treatments except at the end of August 2005, when the dry treatment trees presented lower $\pi_{s}$ than those observed in the other trees (Table 2 and Fig. 6E). No consistent treatment effects could be found on the tree sap flow driving force $\Delta \Psi$ even in July 2005 (Table 2). Despite no statistically significant difference, $G_{t}$ showed a trend for higher average values for the wet treatment during the spring periods (Fig. 6F). It steeply decreased to 3-fold lower values under summer drying conditions, but was unaffected by treatments or the inter-annual variation in drought intensity (Fig. 6 F).

\subsubsection{Leaf gas exchange}

A seasonal trend could be distinguished in leaf gas exchange over the study period (Fig. 7A and B), comparable to the seasonal variation of $\Psi$. Higher $g_{\text {smax }}$ and $A_{\max }$ were observed during the winter and early spring. At the end of the summer drought both parameters were strongly inhibited. Significant differences between treatments in $g_{s \max }$ and $A_{\max }$ were only observed on
July 1 st 2005 , with wet treatment trees showing higher leaf gas exchange rates (Table 2; Fig. 7A-B).

Maximal stomatal conductance steeply decreased with the onset of drought, from June onwards, in 2003 and 2004, whereas it was delayed until July in 2005 in the wet treatment, due to spring irrigation. Stomatal closure was severe at the end of the summer drought, particularly in 2005. The limitation of stomatal conductance was reversed rapidly after the first rains in fall. There was a statistically significant difference in minimum $g_{\text {smax }}$ between years $(p<0.001)$, with overall means of $0.081 \pm 0.009,0.042 \pm 0.003$ and $0.026 \pm 0.004 \mathrm{~mol} \mathrm{~m}^{-2} \mathrm{~s}^{-1}$ in September 2003, 2004 and 2005, respectively (Fig. 7A).

Stomatal closure limited carbon assimilation as $A_{\max }$ variation was quite close to the variation observed in $g_{\text {smax }}$. Compared to $g_{\text {smax }}, A_{\max }$ declined more slowly during the drought stress development but recovered faster later on. Significant differences were also found over the years in minimum $A_{\max }$. Overall means were $6.4 \pm 0.5,3.0 \pm 0.3$ and $1.8 \pm 0.2 \mu \mathrm{mol} \mathrm{m}^{-2} \mathrm{~s}^{-1}$ in September 2003, 2004 and 2005, respectively (Fig. 7B). By the end of the study period, $g_{\text {smax }}$ and $A_{\max }$ values were similar or even higher than in the previous rainy seasons (Fig. 7A and $\mathrm{B}$ ).

No consistent trend could be identified in the intrinsic water use efficiency WUEi, $\left(A_{\max } / g_{s \max }\right)$ in response to increasing drought or treatment effect (data not shown). WUEi was similar at the end of summer 2003, 2004 and 2005.

\subsubsection{Tree growth}

Before treatments were applied, the mean $D B H$ was $11.6 \pm 0.3 \mathrm{~cm}$ with values ranging from 8.6 to 21.0 . Tree heights varied between $4.1 \mathrm{~m}$ and $7.2 \mathrm{~m}$ with an average of $5.3 \pm 0.2 \mathrm{~m}$. Inter-annual trends of tree size and morphological characteristics are presented in Fig. 8. There was no major difference between treatment means but the tree height increase was higher for the wet treatment trees, especially in 2005 (Fig. 8A). An increase in $D B H$ was observed over the whole study period (Fig. 8B). However, the growth rate changed over the years. From 2004 to 2005, a decline in $D B H_{\text {inc }}$ was observed in the ambient treatment. It was significantly more pronounced in the dry treatments (RSC, $p<0.05)$. Inversely, an increase of $D B H_{i n c}$ occurred in the wet treatment $(R S C, p<0.001)$. There was also a highly significant positive impact of irrigation on tree $D B H_{\text {inc }}$ in 2005. Trees from the wet treatment showed a $55 \%$ and $60 \%$ higher $D B H_{\text {inc }}$ than trees from the ambient and dry treatments, respectively (Table 2). Those significant differences in $D B H_{i n c}$ became mostly evident after the last irrigation event in 2005 (data not shown). 


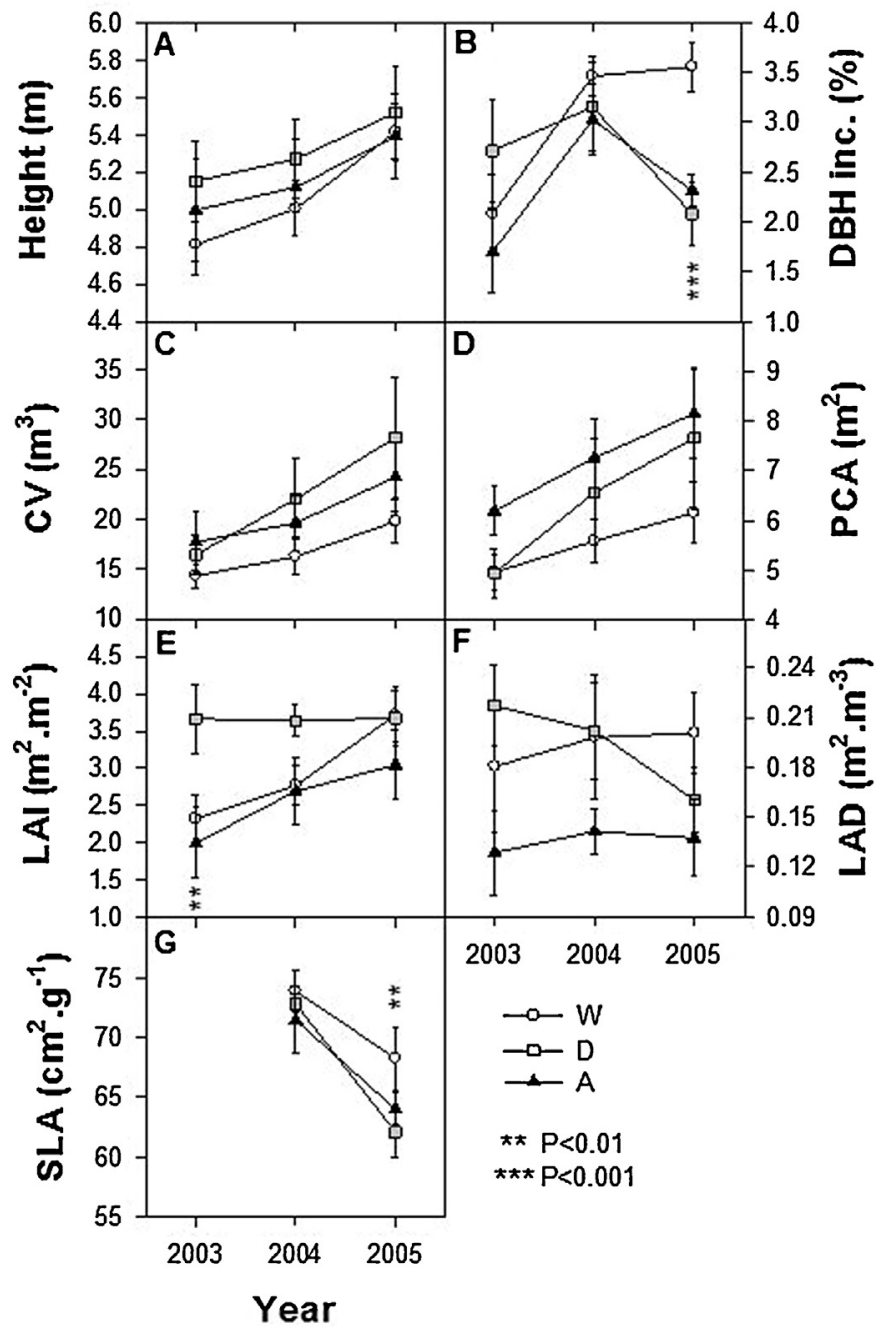

Fig. 8. (A) Tree height, (B) increment of diameter at breast height $\left(D B H_{i n c}\right)$ expressed as percentage of the total diameter, (C) crown volume ( $C V)$, (D) tree projected crown area $(P C A)$, (E) leaf area index $(L A I)$ expressed as leaf $\mathrm{m}^{2}$ per ground $\mathrm{m}^{2}$, (F) leaf area density $(L A D)$ expressed as leaf $\mathrm{m}^{2}$ per crown volume $\mathrm{m}^{3},(\mathrm{G})$ specific leaf area $(S L A)$. Values are average of each treatment and the respective $\operatorname{SEM}(n=9)$. Significant differences between treatments are indicated when ${ }^{* *} P<0.01$, ${ }^{* * *} P<0.001$.

Regressions of $C V$ and $P C A$ against time show significantly higher slopes for trees from the dry treatment compared with those for the wet and ambient treatments ( $R S C, p<0.01)$ between 2003 and 2005 (Fig. 8C and D). Inversely, significantly lower slopes were found for the dry treatment in $L A I$ from 2003 to 2005 (Fig. 8E, RSC, $p<0.001$ ) and $L A D$ from 2004 to 2005 (Fig. 8F, RSC, $p<0.001$ ). The SLA (Fig. 8G) also significantly decreased from 2004 to 2005 for all treatments (Paired $t$-test, $p<0.03$ ). The regression slope was steeper for trees from the dry treatment, and smoother for trees of the wet treatment. SLA regression slopes for trees of the wet and dry treatments were highly significantly different $(R S C, p<0.01)$. At the end of the experiment, SLA also showed significant differences between treatments $(p<0.01)$, with significantly higher values obtained for trees of the wet treatment.

\section{Discussion}

\subsection{Effect of the inter-annual variability in precipitation}

The experiment covered three highly contrasting hydrological years ranging from typical in 2003, to moderately dry in 2004, and severely dry in 2005 . This last hydrological year was the driest in the
Iberian Peninsula over the last 140 years and had major economic repercussions for Portugal and Spain (García-Herrera et al., 2007). There were no major rainfall events between December 2004 and February 2005 , and precipitation only reached $8 \%$ of the long-term average (García-Herrera et al., 2007). It also followed a moderately dry year (2004), which emphasized the subsequent negative impacts on water resources and vegetation growth.

The extreme drought of 2005 led to a decrease in the $D B H_{i n c}$ ( $-24 \%$ in the ambient plot from 2004 to 2005, Fig. 8B) and in the SLA ( $-17 \%$, Fig. $8 \mathrm{G})$. Similar impacts were observed at the ecosystem scale from satellite observations. These observations showed a negative anomaly of the Normalized Difference Vegetation Index (NDVI) in the montado area surrounding our experimental area from March to June 2005 (-13\% of the median average of 1999-2009, data not shown). A comparable drop of the NDVI was also observed at the regional scale (Gouveia et al., 2009). Besides, at the stand scale Boelman et al. (2003) showed that the increase in NDVI was strongly correlated with the increase in the aboveground vegetation biomass and leaf area. Our results confirm those findings for any trends. This suggests that the regional decrease in NDVI observed by satellite by Gouveia et al. (2009) simply results from the decrease of the vegetation $L A I$ at the local scale.

There was a noticeable stomatal regulation response to summer drought intensity (Fig. 7A) and a 66\% reduction of the tree sap flow in the ambient plot (Fig. 2F) at the end of summer 2005 compared with the end of summer 2004 (15/08-15/09). Nonetheless, the accumulated annual tree transpiration did not vary according to the inter-annual variations in precipitation between 2004 and 2005 (Fig. 4A-C). Pereira et al. (2007) had shown similar results in measuring canopy transpiration through eddy covariance in a nearby montado. Limousin et al. (2010) suggested that tree transpiration was regulated by mechanisms adjusting to the eco-hydrological equilibrium and mitigating ecosystem changes in water availability. The authors proposed that leaf area adjustment was one of the mechanisms involved in optimizing the balance between biomass increase and water loss, as previously reported by Eagleson (1982) and Rambal (1992). In our study, inter-annual trends in the $L A I, L A D$, $S L A, D B H, C V$ and $P C A$ (Fig. 8) indicate a slowdown in the leaf biomass production in response to precipitation reduction that is opposite to the canopy size evolution. This conclusion is supported by a stable leaf litterfall amount and an increased branch litterfall amount from 2004 to 2005 (results not shown). These morphological trends show that trees adjusted towards a steady annual accumulated transpiration supporting the hydro-ecological equilibrium theory.

The constant accumulated annual canopy transpiration observed after two contrasting precipitation years (Table 3) strongly suggests the use of groundwater by cork oak. Estimates of the contribution of groundwater to the stand canopy transpiration during the summer (Table 3) support this interpretation. They are in agreement with former estimations obtained from stable isotope analyses at the tree level (David et al., 2007; Kurz-Besson et al., 2006; Otieno et al., 2007). Deep rooting and groundwater taping provide cork oak a drought avoidance strategy conferring trees a high adaptability under scarce and variable water resources. Our results show that groundwater used through deep rooting is to be considered as a contributing mechanism towards the eco-hydrological equilibrium in savannah-like oak woodland Mediterranean ecosystems, buffering changes in the ecosystem transpiration regardless of large inter-annual variations in precipitation.

There was a larger relative contribution of groundwater to the stand canopy transpiration in summer 2005 (86\%) compared with summer 2004 (57\%) (Table 3). However, the amount of groundwater used by trees was similar in 2004 and 2005. This suggests that the groundwater discharge by deep rooting taping was 
little affected by the extreme dry year of 2004-2005. All these results raise further questions about the mechanisms regulating the amount of groundwater extracted by Cork oak's roots and the long-term effects of increasing droughts on the level of superficial groundwater.

\subsection{Effects of rainfall manipulation on physiological responses and growth of cork oak}

As illustrated by Table 2, there was hardly any significant treatment effect on instantaneous measurements of $\Psi, A$ or gs, (except one week after the isolated late spring irrigation pulse). Our results contrast with the significant effects reported in rainfall exclusion experiments in Mediterranean woodlands. Alberti et al. (2007) applied the same dry and wet treatments as we did in an Arbutus unedo woodland in Italy, and reported a $20 \%$ reduction of the ecosystem gross primary productivity in 2005 and 35\% reduction in ecosystem evapotranspiration between the wet and dry treatments. Under a precipitation input reduction of $29 \%$, Limousin et al. (2009) reported a continuous reduction of tree transpiration, resulting in a $23 \%$ reduction in annual transpiration.

In our experiment, the wet, ambient and dry treatments received $77 \%, 61 \%$ and $50 \%$ of the long-term average precipitation in 2005 , respectively. Thus the entire experimental plot experienced severe water stress regardless of the imposed treatment. This might partly explain the weak and irregular impact of the treatments on cork oak's water status and gas exchange in 2005. Nonetheless, tree transpiration differed significantly between trees from the three treatments during summer droughts (Fig. 2F). Rainfall exclusion had an effect on canopy transpiration at the stand level, as we measured a $20-27 \%$ reduction of transpiration during summer in the dry plots, compared to the ambient ones. In comparison, the annual transpiration only decreased of 8 to $13 \%$ (Table 3 ). By contrast, the irrigation increased the canopy transpiration by $14 \%$ and $63 \%$ during the 2004 and 2005 summers, respectively, and by only 8-13\% on an annual basis.

Cork oak SLA reduction from 2004 to 2005 was $10.4 \%$ (ambient treatment). It was less pronounced in the wet treatment $(-7.6 \%)$ and more pronounced in the dry treatment $(-14.7 \%)$. Compared with the other plots, $L A I$ and $L A D$ from the dry plots showed significant opposite trends $(R S C, p<0.001)$, which confirms the tendency for leaf area reduction under water shortage. Our results are in agreement with the $L A I$ reduction previously observed by Limousin et al. (2010).

No significant treatment effect was found in $C V$ and PCA. This might be explained by the non-limiting soil moisture during the 3 months preceding leaf unfolding in 2005 (Fig. 2E and 3), as previously suggested by Pinto et al. (2012). The last isolated spring irrigation, which occurred after full shoot elongation may also explain the absence of treatment effect on PCA and $C V$. This agrees with the absence of significant treatment effect on leaf stomatal conductance and carbon assimilation during the shoot elongation period. The conclusion is also consistent with the results of Fotelli et al. (2000), who did not find any effect of water deficits on seedling height increment while studying the physiological response of 4 oak species to water shortage.

Precipitation interception by tree crowns did not reduce the exclusion efficiency enough to explain the weakness or discontinuity of the treatment effect observed in trees from the dry treatment. In our experiment, the tree density was lower and the applied water regimes had a lower contrast than most of the other experiments performed in Mediterranean woodlands (Alberti et al., 2007; Limousin et al., 2009, 2010; Misson et al., 2010; Cotrufo et al., 2011). These characteristics associated with the use of groundwater by trees might explain the weak impact of rainfall exclusion in our study.
In our experimental plot, the low soil water holding capacity ( $5 \%$, $50 \mathrm{~mm}$ water reservoir between the surface and $1 \mathrm{~m}$ depth) lowered the ability of the ecosystem to buffer water fluctuations, an effect previously proposed by Beier et al. (2012). This soil characteristic is likely to result in a reduced irrigation efficiency, especially when irrigation was applied immediately after rain events.

\subsection{The relevance of precipitation and irrigation during spring}

The accumulated tree transpiration matched the precipitation amount at the stand level in spring 2004 and 2005 (Table 3). This suggests that stand canopy transpiration and gas exchange in spring are mostly limited by the shallow soil water availability at the peak of the growing season. A previous study conducted in the same experimental plot showed that trees were relying on precipitation and shallow soil water from fall to spring (Kurz-Besson et al., 2006). After late June, the soil water potential $\left(\psi_{s}\right)$ in the main rhizosphere horizon ( $\sim-0.3 \mathrm{~m}$ depth) rapidly decreased until $-1.5 \mathrm{MPa}$. Then $\psi_{s}$ started to decrease and fluctuate in the deeper horizon, suggesting new root growth. As summer drought progressed, trees relied more on groundwater and redistributed water from hydraulic lift (David et al., 2007; Otieno et al., 2006; KurzBesson et al., 2006).

Irrigation events were intentionally delayed during spring 2005 to reduce dry spell duration in the wet treatment at a critical time for the ecosystem water availability. At this time of the year, the high solar radiation coupled with increasing temperatures and usually not yet limited water availability provide trees the best meteorological conditions for maximum stomatal aperture, carbon assimilation and transpiration. Thus a larger impact of water manipulation is expected during this period.

Late spring irrigation pulses in 2005 led to a transitory but significantly better physiological performance of trees from the wet treatment. A significant positive impact was found on most of the physiological parameters measured on July 1 st. This positive effect could not be detected in the measurements performed the following weeks, despite the significant treatment differences found in soil water content (Table 2). Tree transpiration response to the last irrigation of June 2005 coincided with the higher soil moisture observed at $0.3 \mathrm{~m}$ depth (Fig. $2 \mathrm{E}$ and $\mathrm{F}$, dashed line). On July 1 st, midday leaf water potential in trees was already reaching $-2 \mathrm{MPa}$, indicating that fine roots in the main soil rhizosphere layer $(\sim 0.3-0.4 \mathrm{~m})$ were severely stressed and probably dying. The delay of a few days in using irrigated water from the top-soil horizons might be due to the necessity for trees to grow new fine roots (or repair damaged fine roots) to be able to extract water from the soil.

The transient physiological response of wet treatment trees to spring irrigation had a relevant impact on stem diameter growth resulting in a 32\% increase between June and November 2005, while it only reached $17 \%$ in the ambient and dry treatments. In 2004 $\mathrm{DBH}_{\text {inc }}$ reached $30 \%$ in each treatment over the same period. This suggests that the spring irrigation in 2005 compensated the negative impact of the extreme dry year 2005 observed for $D B H_{i n c}$ on trees from the dry and ambient plots. Furthermore the differences in $D B H_{\text {inc }}$ between trees from the wet and the other treatments became significant from the end of spring until the end of fall 2005 (data not shown). This reveals a high-impact benefit of spring water supplement on tree stem growth and a fast integration of carbon assimilated by leaves to stem biomass after July 1st 2005 (Table 2 and Figs. 2, 5, 6 and 8). A substantial increase of stem biomass in response to irrigation in a Mediterranean forest dominated by Arbutus unedo was also reported by Cotrufo et al. (2011).

The constant exclusion of water in the dry treatment-reducing the precipitation quantity without changing rainfall distributionhad a low impact on stem growth (Table 2). Although the study of the effect of precipitation distribution was not in the scope of 
this work, our findings not only highlight the importance of precipitation quantity on plant physiology, but also its timing. Our results indicate that changes in spring precipitation may have a stronger impact on cork oak physiology and growth than the overall change in the annual precipitation in a semi-arid environment. Similar conclusions were proposed by Beier et al. (2012). Further experiments should be performed to figure out whether spring precipitation quantity, frequency (dry spell duration and/or number of rainy days), or timing has the main influence on cork oak physiological responses. This is of a crucial importance to better predict cork oak vulnerability under climate change, given that both precipitation quantity and the number of rainy days in spring decreased over the last 50 years (Gallego et al., 2011; Miranda et al., 2006; Paredes et al., 2006), with potential consequences for river flow and subsurface water sources (Paredes et al., 2006).

\subsection{Cork oak drought avoidance strategies and resilience}

Independently of the severity of droughts, a full recovery of photosynthetic capacity was observed after fall precipitation (Fig. 7). Stomatal closure accompanied by a decrease in leaf water potential is a characteristic response of Mediterranean species to seasonal water deficit, which confers xeric plants with a conservative water use (Acherar and Rambal, 1992; Tenhunen et al., 1981). As drought persists, the resulting water deficits may cause cavitation in xylem vessels along the root to leaf pathway, and thus compromise xylem transport (Cochard et al., 1996). Cavitation may sequentially lead to the occurrence of embolism, impairing water delivery to living tissues, which might kill the tree (Pereira et al., 2009). Xylem vulnerability to embolism is thus closely linked to the minimum $\Psi_{m d}$ at which xylem dysfunctions occur. To avoid catastrophic damage in the root-leaf hydraulic pathway, leaf stomata evolved to control and restrain water losses so that plant water status is maintained above the minimum $\Psi_{m d}$ threshold of xylem runaway embolism, thus preventing the plant from losing its water transport capability (Jones and Sutherland, 1991; Tyree and Sperry, 1988). The lowest mean value of $\Psi_{m d}$ measured in our study at the end of the summer 2004 and $2005(-3.28 \pm 0.06 \mathrm{MPa})$ is close to the water potential causing $50 \%$ loss in hydraulic conductivity, which is a proxy of the species hydraulic safety margin before xylem dysfunction (Pinto et al., 2012).

With persistent drought, $Q$. suber showed a marked decrease of leaf osmotic potential associated to the raise of leaf solute content, which suggests the occurrence of osmotic adjustment at the leaf level. However, while leaf solute content was kept high throughout the drought period in 2004, a decrease of $\pi_{s}$ was observed in the mid-summer of 2005. Such a decrease has also been reported by Abrams (1990) and Kwon and Pallardy (1989). It was likely due to metabolic impairment associated with the prolonged water stress experienced by the trees (Chaves et al., 2002; Liu et al., 2011). Nevertheless, the accumulation of solutes in cells promoting water absorption enabled a positive leaf turgor up to values of $\Psi_{p d}$ around $-2.0 \mathrm{MPa}$ (Fig. 5). Our results agree with previous studies showing that several Mediterranean evergreen oak species including $Q$. suber possess the capacity to osmotically adjust (Aranda et al., 2005; Corcuera et al., 2002; Parker and Pallardy, 1988) and reduce leaf cell wall elasticity in response to drought (Nardini et al., 1999; Otieno et al., 2006; Pardos et al., 2005). These mechanisms acting together enhance tree potential to extract water from the drying soils by increasing the soil-plant water potential gradient, thus avoiding an excessive dehydration of the cells.

Leaf surface reduction is a further protective mechanism of dehydration avoidance restraining water loss while maximizing carbon gain, and keeping minimum $\Psi_{m d}$ above the threshold of xylem embolism under increasing drought intensity. Lower SLA has long been shown to be an adaptive response to drought
(Abrams, 1994; Cunningham et al., 1999; Grünzweig et al., 2008) or an indicator of resource conditions (Cornelissen et al., 2003). Ramírez-Valiente et al. (2011) found that cork oak's SLA was negatively correlated with annual shoot growth and positively related to annual growth. This is in good agreement with the opposite trends we observed between SLA, CV and PCA (Fig. 8). With increasing drought severity, leaf area reduction is often related to an increase in the root:shoot biomass indicating allocation adjustments favouring the root system (Fernández and Reynolds, 2000). The growth of new roots in deeper soil layers in response to increasing drought stress has also been shown both for cork oak trees in the same experimental plot by Otieno et al. (2006) and for desert plants species (Fernandez and Caldwell, 1975; Peek et al., 2006).

\section{Concluding remarks}

Our study shows that inter-annual differences in precipitation affects cork oak annual trunk growth, leaf area and summer transpiration rate. In particular cork oak physiology and growth are critically sensitive to spring precipitations. This was evidenced by the remarkable cork oak physiological performances following late spring irrigation in 2005 , which compensated the negative impacts of the extreme drought of the hydrological year 2004/2005.

Several studies (Knapp et al., 2008; Misson et al., 2010) suggested that rainfall distribution pattern could have larger physiological impacts on oaks than a reduction in precipitation, but our study shows the dominant impact of precipitation in late spring. This might weaken cork oak endurance to drought, especially when the Iberian Peninsula has shown a significant 50\% $(\sim 40 \mathrm{~mm})$ decrease of precipitation in March over the last four decades (Gaetani et al., 2011; Paredes et al., 2006), and when drought events are predicted to occur more frequently in April and May in the future in Portugal (Miranda et al., 2002). Studying climate change trends over the last 50 years, Gallego et al. (2011) also showed that the Mediterranean region suffered a reduction of the number of rainy days in spring. It is, therefore, not surprising that the southern Iberian Peninsula is expected to be the Mediterranean area most affected by lower groundwater recharges in the future (Hiscock et al., 2011) and most threatened by desertification (Acácio et al., 2009).

Such changes in the amount and distribution of spring rainfall, and in groundwater recharge are likely to severely affect $Q$. suber in the Iberian Peninsula. By inducing water stress before the onset of summer droughts, spring precipitation changes will probably drive the species closer to the threshold of catastrophic xylem embolism by imposing narrower hydraulic safety margins at the peak of the drought period (Franks et al., 2007; McDowell et al., 2008). This is already suggested by the evident signs of decline of the species over the last decade in Portugal (AFN, 2001, 2010).

On the other hand, our study shows that cork oak rapidly and completely recovered from the extreme dry year of 2005 or rainfall exclusion. Trees did not exhibit significant signs of increased vulnerability to the reduction of precipitation amount. This reflects how well the species has adapted to the high variability of precipitation in the Mediterranean climate.

The $20 \%$ rainfall exclusion applied during two consecutive years had little significant impact on cork oak physiology. The study of Martin-StPaul et al. (2013) suggested that Quercus ilex growth (height and $D B H$ ) presents a delayed response to changes in water availability. Also, longer rainfall exclusion experiments have shown that deleterious cumulative effects sometimes only appear after 3 or more years of treatment application, or under more drastic treatments (Brando et al., 2010; da Costa et al., 2010; Limousin et al., 2010). Therefore, additional longer exclusion experiments should 
be promoted to test for long-term cumulative effects of precipitation changes on cork oak species and montado ecosystems.

The cork oak savannah-type ecosystem showed a high degree of resilience in response to inter-annual precipitation variability or imposed water shortage. Our results showed that this resilience partly relies on deep rooting and the use of groundwater as a drought avoidance strategy. Our results raise nonetheless the question of the evolution of the ecosystem sustainability under climate changes if those provoke a decrease of river flow or an increase of anthropogenic pressure on water resources leading to a recurrent decline of groundwater table level as suggested by recent investigations (Estrela et al., 1996; Nohara et al., 2006; Paço et al., 2009; Paredes et al., 2006).

\section{Acknowledgments}

This work was supported by the "Fundação para a Ciência e a Tecnologia" (SFRH/BPD/47021/2008 and PestOE/CTE/LA0019/2011-IDL), and was performed under the European MIND-EVK2-CT-2002-00158 (Mediterranean terrestrial ecosystems and INcreasing Drought: vulnerability assessment) Project financed by the European Community. We also are very grateful to João Banza, Elisabete Marianito, Carla Nogueira, for their technical support for field installation, and to André Pestana and Elsa Breia for their technical contribution with leaf gas exchange measurements. The authors thank the journal referees for providing constructive comments resulting in the improvement of the manuscript.

\section{References}

Abrams, M.D., 1990. Adaptations and responses to drought in Quercus species of North America. Tree Physiol. 7 (1-4), 227-238.

Abrams, M.D., 1994. Genotypic and phenotypic variation as stress adaptations in temperate tree species: a review of several case studies. Tree Physiol. 14 (7-8-9), $833-842$.

Acácio, V., Holmgren, M., Rego, F., Moreira, F., Mohren, G., 2009. Are drought and wildfires turning Mediterranean cork oak forests into persistent shrublands. Agrofor. Syst. 76 (2), 389-400.

Acherar, M., Rambal, S., 1992. Comparative water relations of four Mediterranean oak species. Plant Ecol. 99-100 (1), 177-184.

AFN, 2001. Inventário Florestal Nacional: Portugal continental. $3 \underline{a}$ revisão: 1995-1998. Autoridade Florestal Nacional, Lisboa, Portugal.

AFN, 2010. $5^{\circ}$ Inventário Florestal Nacional (2005-2006). Relatório final. Autoridade Florestal Nacional, Lisboa.

Alberti, G., et al., 2007. Cambiamenti nel regime pluviometrico in ecosistemi mediterranei: il progetto MIND. iForest - Biogeosci.or. 4 (1), 460-468.

Aranda, I., Castro, L., Pardos, M., Gil, L., Pardos, J.A., 2005. Effects of the interaction between drought and shade on water relations, gas exchange and morphological traits in cork oak (Quercus suber L.) seedlings. Forest Ecol. Manag. 210 (1-3), 117-129.

Barriopedro, D., Fischer, E.M., Luterbacher, J., Trigo, R.M., García-Herrera, R., 2011. The hot summer of 2010: redrawing the temperature record map of Europe. Science 332 (6026), 220-224.

Beier, C., et al., 2012. Precipitation manipulation experiments-challenges and recommendations for the future. Ecol. Lett. 15 (8), 899-911.

Berlyn, G.P., 1962. Some size and shape relationships between tree stems and crowns. Iowa State J. Res. 37, 7-15.

Boelman, N.T., et al., 2003. Response of NDVI, biomass, and ecosystem gas exchange to long-term warming and fertilization in wet sedge tundra. Oecologia 135 (3), 414-421.

Bota, J., Medrano, H., Flexas, J., 2004. Is photosynthesis limited by decreased Rubisco activity and RuBP content under progressive water stress? New Phytol. 162 (3), 671-681.

Brando, P.M., et al., 2010. Seasonal and interannual variability of climate and vegetation indices across the Amazon. Proc. Natl. Acad. Sci. U.S.A. 107 (33), $14685-14690$

Bucci, S.J., et al., 2005. Mechanisms contributing to seasonal homeostasis of minimum leaf water potential and predawn disequilibrium between soil and plant water potential in Neotropical savanna trees. Trees Struct. Funct. 19 (3), 296-304.

Bugalho, M.N., Caldeira, M.C., Pereira, J.S., Aronson, J., Pausas, J.G., 2011. Mediterranean cork oak savannas require human use to sustain biodiversity and ecosystem services. Front. Ecol. Environ. 9 (5), 278-286.

Chaves, M.M., 1991. Effects of water deficits on carbon assimilation. J. Exp. Bot. 42 (234), 1-16.
Chaves, M.M., Flexas, J., Pinheiro, C., 2009. Photosynthesis under drought and salt stress: regulation mechanisms from whole plant to cell. Ann. Bot. 103 (4), $551-560$.

Chaves, M.M., Maroco, J.P., Pereira, J.S., 2003. Understanding plant responses to drought - from genes to the whole plant. Funct. Plant. Biol. 30 (3), 239-264.

Chaves, M.M., Oliveira, M.M., 2004. Mechanisms underlying plant resilience to water deficits: prospects for water-saving agriculture. J. Exp. Bot. 55 (407), 2365-2384.

Chaves, M.M., et al., 2002. How plants cope with water stress in the field. Photosynthesis and growth. Ann. Bot. 89, 907-916.

Cochard, H., Breda, N., Granier, A., 1996. Whole tree hydraulic conductance and water loss regulation in Quercus during drought: evidence for stomatal control of embolism? Ann. For. Sci. 53 (2/3), 197

Corcuera, L.C., Camarero, J.J., Gil-Pelegrín, E.G.-P., 2002. Functional groups in Quercus species derived from the analysis of pressure-volume curves. Trees Struct. Funct. 16 (7), 465-472.

Cornelissen, J.H.C., et al., 2003. A handbook of protocols for standardised and easy measurement of plant functional traits worldwide. Aust. J. Bot. 51 (4), 335-380.

Cotrufo, M.F., et al., 2011. Decreased summer drought affects plant productivity and soil carbon dynamics in a Mediterranean woodland. Biogeosciences 8 (9), 2729-2739.

Coumou, D., Rahmstorf, S., 2012. A decade of weather extremes. Nature Clim. Change 2 (7), 491-496.

Cunningham, S.A., Summerhayes, B., Westoby, M., 1999. Evolucionary divergences in leaf structure and chemistry, comparing rainfall and soil nutrient gradients. Ecol. Monog. 69 (4), 569-588.

da Costa, A.C.L., et al., 2010. Effect of 7 yr of experimental drought on vegetation dynamics and biomass storage of an eastern Amazonian rainforest. New Phytologist 187 (3), 579-591.

David T. S., Intercepção da precipitação e transpiração e m árvores isoladas de Quercus rotundifolia Lam. Dissertação de Doutoramento. Universidade Técnica de Lisboa, Instituto Superior de Agronomia, Lisboa, 2000, 155 pp.

David, T.S., Ferreira, M.I., Cohen, S., Pereira, J.S., David, J.S., 2004. Constraints on transpiration from an evergreen oak tree in southern Portugal. Agr. Forest. Meteorol. $122,193-205$

David, T.S., et al., 2007. Water-use strategies in two co-occurring Mediterranean evergreen oaks: surviving the summer drought. Tree Physiol. 27 (6), 793-803.

Diggle, P.J., Heagerty, P., Liang, K.-Y., Zeger, S.L., 2002. Analysis of Longitudinal Data. Oxford Statistical Science Series, 2nd ed. Oxford University Press Inc., New York, pp. 379.

Eagleson, P.S., 1982. Ecological optimality in water-limited natural soilvegetation systems: 1 . Theory and hypothesis. Water Resour. Res. 18 (2), 325-340.

Estrela, T., Marcuello, C., Iglesias, A., 1996. Water Resources. Problems in Southern Europe. An Overview Report. European Environment Agency, Copenhagen.

Evangelista, M., 2010. Relatório da caracterização da fileira florestal 2010. Associação para a competitividade da indústria da fileira florestal, Portugal, pp. 80

Faria, T., et al., 1996. Diurnal changes in photoprotective mechanisms in leaves of cork oak (Quercus suber) during summer. Tree Physiol. 16 (1/2), 115-123.

Farquhar, G.D., Sharkey, T.D., 1982. Stomatal conductance and photosynthesis. Ann. Rev. Plant Phys. 33, 317-345.

Fernandez, O.A., Caldwell, M.M., 1975. Phenology and dynamics of root growth of three cool semi-desert shrubs under field conditions. J. Ecol. 63 (2), 703-714.

Fernández, R.J., Reynolds, J.F., 2000. Potential growth and drought tolerance of eight desert grasses: lack of a trade-off? Oecologia 123 (1), 90-98.

Fotelli, M.N., Radoglou, K.M., Constantinidou, H.-I.A., 2000. Water stress responses of seedlings of four Mediterranean oak species. Tree Physiol. 20 (16), 1065-1075.

Franks, P.J., Drake, P.L., Froend, R.H., 2007. Anisohydric but isohydrodynamic: seasonally constant plant water potential gradient explained by a stomatal control mechanism incorporating variable plant hydraulic conductance. Plant Cell Environ. 30 (1), 19-30.

Gaetani, M., Baldi, M., Dalu, G.A., Maracchi, G., 2011. Jetstream and rainfall distribution in the Mediterranean region. Nat. Hazards Earth Syst. Sci. 11 (9), 2469-2481.

Gallego, M.C., et al., 2011. Trends in frequency indices of daily precipitation over the Iberian Peninsula during the last century. J. Geophys. Res. 116 (D2), D02109.

García-Herrera, R., et al., 2007. The outstanding 2004/05 drought in the Iberian Peninsula: associated atmospheric circulation. J. Hydrometeorol. 8 (3), 483-498,

Giorgi, F., Lionello, P., 2008. Climate change projections for the Mediterranean region. Global planet. Change 63 (2-3), 90-104.

Gouveia, C., Trigo, R.M., DaCamara, C.C., 2009. Drought and vegetation stress monitoring in Portugal using satellite data. Nat. Hazards Earth Syst. Sci. 9 (1), 185-195.

Granier, A., 1985. Une nouvelle méthode pour la mesure du flux de sève brute dans le tronc des arbres. Ann. For. Sci. 42 (2), 193-200.

Grant, O.M., et al., 2010. The impact of drought on leaf physiology of Quercus suber $\mathrm{L}$. trees: comparison of an extreme drought event with chronic rainfall reduction. J. Exp. Bot. 61 (15), 4361-4371.

Grassi, G., Magnani, F., 2005. Stomatal, mesophyll conductance and biochemical limitations to photosynthesis as affected by drought and leaf ontogeny in ash and oak trees. Plant Cell Environ. 28 (7), 834-849.

Grünzweig, J.M., et al., 2008. Growth, resource storage, and adaptation to drought in California and eastern Mediterranean oak seedlings. Can. J. For. Res. 38 (2), 331-342.

Hiscock, K., Sparkes, R., Hodgson, A., 2011. Evaluation of future climate change impacts on European groundwater resources. In: Holger Treidel, J.L.M.-B., Gurdak, Jason J. (Eds.), Climate Change Effects on Groundwater Resources: A Global Synthesis of Findings and Recommendations. IAH - International Contributions to Hydrogeology. CRC Press, Taylor \& Francis Group, London, UK, p. 414 pages. 
ICNF, 2013. IFN6 - Áreas dos usos do solo e das espéciesflorestais de Portugal continental. Resultados preliminares. Instituto da Conservação daNatureza e das Florestas, Lisboa.

INMG, 1991. O Clima em Portugal. Normais climatológicas da região do Alentejo e Algarve, correspondentes a 1951-1980. Fascículo XLIX, 4-4a. Instituto Nacional de Moteorologia e Geofísica, Portugal, pp. 98.

IPCC, 2007. Fourth Assessment Report. Summary for Policymakers: Climate Change. The Physical Science Basis. IPCC.

Jones, H.G., Sutherland, R.A., 1991. Stomatal control of xylem embolism. Plant Cell Environ. 14 (6), 607-612.

Knapp, A.K., et al., 2008. Consequences of more extreme precipitation regimes for terrestrial ecosystems. Bioscience 58 (9), 811-821.

Kurz-Besson, C., et al., 2006. Hydraulic lift in cork oak trees in a savannah-type Mediterranean ecosystem and its contribution to the local water balance. Plant Soil 282 (1-2), 361-378.

Kwon, K.W., Pallardy, S.G., 1989. Temporal changes in tissue water relations of seedlings of Quercus acutissima, Q. alba, and Q. stellata subjected to chronic water stress. Can. J. For. Res. 19 (5), 622-626.

Lawlor, D.W., Cornic, G., 2002. Photosynthetic carbon assimilation and associated metabolism in relation to water deficits in higher plants. Plant Cell Environ. 25 (Part 2), 275-294.

Lawlor, D.W., Tezara, W., 2009. Causes of decreased photosynthetic rate and metabolic capacity in water-deficient leaf cells: a critical evaluation of mechanisms and integration of processes. Ann. Bot. 103 (4), 561-579.

Limousin, J.-M., Longepierre, D., Huc, R., Rambal, S., 2010. Change in hydraulic traits of Mediterranean Quercus ilex subjected to long-term throughfall exclusion. Tree Physiol. 30 (8), 1026-1036.

Limousin, J.M., et al., 2009. Long-term transpiration change with rainfall decline in a Mediterranean Ouercus ilex forest. Global Change Biol. 15 (9), 2163-2175.

Liu, C., et al., 2011. Effect of drought on pigments, osmotic adjustment and antioxidant enzymes in six woody plant species in karst habitats of southwestern China. Environ. Exp. Bot. 71 (2), 174-183.

Martin-StPaul, N.K., Limousin, J.M., Vogt-Schilb, H., Rodrıguez-Calcerrada, J., Rambal, S., Longepierre, D., Misson, L., 2013. The temporal response to drought in a Mediterranean evergreen tree: comparing a regional precipitation gradient and a throughfall exclusion experiment. Global Change Biol. 19, 2413-2426.

McDowell, N., et al., 2008. Mechanisms of plant survival and mortality during drought: why do some plants survive while others succumb to drought? New Phytol. 178 (4), 719-739.

Miranda, P., Coelho, F., Tomé, A., Valente, M., 2002. 20th century Portuguese climate and climate scenarios. In: Santos, F.D., Forbes, K., Moita, R. (Eds.), Climate Change in Portugal, Impacts and Adaptation Measures - SIAM Project. Gradiva, Lisboa, p. 454.

Miranda, P.M.A., et al., 2006. O clima de Portugal nos séculos XX e XXI. In: Santos, F.D., Miranda, P.M.A. (Eds.), Alterações climáticas em Portugal Cenários, impactes e medidas de adaptação. Gradiva, Lisboa, pp. 45-113.

Misson, L., Limousin, J.-M., Rodriguez, R., Letts, M.G., 2010. Leaf physiological responses to extreme droughts in Mediterranean Quercus ilex forest. Plant Cell Environ. 33 (11), 1898-1910.

Nardini, A., Lo Gullo, M.A., Salleo, S., 1999. Competitive strategies for water availability in two Mediterranean Quercus species. Plant Cell Environ. 22 (1), 109-116.

Nohara, D., Kitoh, A., Hosaka, M., Oki, T., 2006. Impact of climate change on river discharge projected by multimodel ensemble. J. Hydrometeorol. 7 (5), 1076-1089

Otieno, D.O., et al., 2006. Seasonal variations in soil and plant water status in a Quercus suber L. Stand: roots as determinants of tree productivity and survival in the mediterranean-type ecosystem. Plant Soil 283 (1-2), 119-135.
Otieno, D.O., et al., 2007. Regulation of transpirational water loss in Quercus suber trees in a Mediterranean-type ecosystem. Tree Physiol. 27 (8), 1179-1187.

Paço, T.A., et al., 2009. Evapotranspiration from a Mediterranean evergreen oak savannah: the role of trees and pasture. J. Hydrol. 369 (1-2), 98-106.

Pardos, M., Jimenez, M.D., Aranda, I., Puertolas, J., Pardos, J.A., 2005. Water relations of cork oak (Quercus suber L.) seedlings in response to shading and moderate drought. Ann. For. Sci. 62 (5), 377-384.

Paredes, D., Trigo, R.M., Garcia-Herrera, R., Trigo, I.F., 2006. Understanding precipitation changes in Iberia in early spring: weather typing and storm-tracking approaches. J. Hydrometeorol. 7 (1), 101-113.

Parker, W.C., Pallardy, S.G., 1988. Leaf and root osmotic adjustment in droughtstressed Quercus alba, Q. macrocarpa, and Q. stellata seedlings. Can. J. For. Res. 18 (1), $1-5$.

Peek, M.S., et al., 2006. Root turnover and relocation in the soil profile in response to seasonal soil water variation in a natural stand of Utah juniper (Juniperus osteosperma). Tree Physiol. 26 (11), 1469-1476.

Pereira, J.S., Kurz-Besson, C., Chaves, M.M., 2009. Coping with drought. In: Aronson, J., Pereira, J.S., Pausas, J.G. (Eds.), Cork oak woodlands on the edge: ecology, adaptive management, and restoration. Part II. Scientific Bases for restoration and management. Island Press, Washington, DC, p. 73-80.

Pereira, J.S., et al., 2007. Net ecosystem carbon exchange in three contrasting Mediterranean ecosystems - the effect of drought. Biogeosciences 4 (5) 791-802.

Philandras, C.M., et al., 2011. Long term precipitation trends and variability within the Mediterranean region. Nat. Hazards Earth Syst. Sci. 11 (12), 3235-3250.

Pinto, C.A., et al., 2012. Drought-induced embolism in current-year shoots of two Mediterranean evergreen oaks. Forest Ecol. Manag. 285 (0), 1-10.

Rambal, S., 1992. Quercus ilex facing water stress: a functional equilibrium hypothesis. Plant Ecol. 99-100 (1), 147-153.

Ramírez-Valiente, J., Valladares, F., Delgado Huertas, A., Granados, S., Aranda, I., 2011 Factors affecting cork oak growth under dry conditions: local adaptation and contrasting additive genetic variance within populations. Tree Genet. Genomes 7 (2), 285-295

Sardans, J., Peñuelas, J., 2013. Plant-soil interactions in Mediterranean forest and shrublands: impacts of climatic change. Plant Soil 365 (1-2), 1-33.

Tenhunen, J.D., Lange, O.L., Braun, M., 1981. Midday stomatal closure in Mediterranean type sclerophylls under simulated habitat conditions in an environmental chamber. Oecologia 50 (1), 5-11.

Tezara, W., Mitchell, V.J., Driscoll, S.D., Lawlor, D.W., 1999. Water stress inhibits plant photosynthesis by decreasing coupling factor and ATP. Nature 401 (6756) 914-917.

Tyree, M.T., Sperry, J.S., 1988. Do woody plants operate near the point of catastrophic xylem dysfunction caused by dynamic water stress? Plant Physiol. 88 (3), 574-580.

Vaz, M., et al., 2010. Drought-induced photosynthetic inhibition and autumn recovery in two Mediterranean oak species (Quercus ilex and Quercus suber). Tree Physiol. 30 (8), 946-956.

Watson, D.J., 1947. Comparative physiological studies on the growth of field crops 1. Variation in net assimilation rate and leaf area between species and varieties, and within and between years. Ann. Bot. 11 (41), 41-76.

Wesely, M.L., 1989. Parameterization of surface resistances to gaseous dry deposition in regional-scale numerical models. Atmos. Environ. 23 (6), 1293-1304.

Wu, Z., Dijkstra, P., Koch, G.W., Peñuelas, J., Hungate, B.A., 2011. Responses of terrestrial ecosystems to temperature and precipitation change: a meta-analysis of experimental manipulation. Global Change Biol. 17, 927-942.

Zar, J.H., 1999. Biostatistical Analysis, 4th ed. Prentice Hall, Upper Saddle River, New Jersey, 998 pp. 